\title{
MICROCITY: \\ Rehabilitating St. James Town, Toronto's First Towers-in-the-Park Community
}

Khoi Nguyen B.A.S.

\begin{abstract}
A thesis submitted to the Faculty of Graduate and Postdoctoral Affairs in partial fulfilment

of the requirement for the degree of
\end{abstract}

Master of Architecture in

M. Arch, Professional

Azreili School of Architecture and Urbanism

Carleton University

Ottawa, Ontario

(c) 2014

Khoi Nguyen 


\section{ABSTRACT}

The 1960s in Toronto marked a turn in the city's housing typology from a "City of

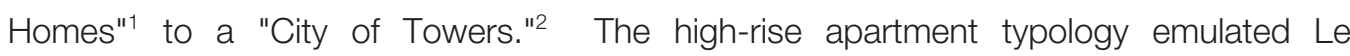
Corbusier's housing form in Europe and was the darling of planners and developers. These towers' popularity surged from the onset of the 1960s to the end of the 1970s. This new urban vision for high density living adopted the moniker of "Towers in the Park" and was based on the act of setting tall apartment towers in the centre of a city block surrounded by a lush green landscape. ${ }^{3}$ These vertical communities, emblems of modernity, were envisioned to symbolize a new metropolis and opposed the suburbanization that lured the middle class away from the commotion, real, and imagined perils of the city. What was meant to be a refuge for the middle class, however, soon transformed into vertical villages for the low-income and newly arrived immigrants. The towers have defaulted to crumbling pieces of concrete and masonry, and their parks have diminished to patchy lawns and crumbled paving. This thesis investigates the forces that led to the deterioration of these structures and the state of the communities within them. The design proposal aims to provide an architectural and landscape planning strategy to rehabilitate the first neighbourhood of this kind in Toronto, St. James Town, to become a vibrant and healthy microcosm of the city.

\footnotetext{
${ }^{1}$ Chris Hardwicke, "City of Homes", Spacing, (Spring 2010), 58.

2 E.R.A. Architects and the University of Toronto, Mayor's Tower Renewal Opportunities Book (Toronto, Ontario: City of Toronto, 2008); quoted in United Way Toronto, Poverty by Postal Code2: Vertical Poverty (Toronto, Ontario: United Way, 2013), 28.
}

Le Corbusier translated by Frederick Etchells, Towards a New Architecture (New York: Dover Publications Inc. 1986), 57. 


\section{ACKNOWLDGE $N$ IIS}

First and foremost, I would like to express my gratitude to my advisor, Paul Kariouk, for his steadfast professionalism, patience, and time in guiding me through the completion of this thesis.

I would like to thank my parents for all of the sacrifices they have made. This thesis is a testament to their unconditional support which allowed me to pursue my interests and life goals.

I would like to extend a special thank you to my partner, Dorothy, to whom I am indebted for her countless hours editing this thesis, while providing me with the encouragement to push forward and the distractions to keep me sane.

Lastly, I am thankful for all the friends that I have made along the way --- until we meet again. 


\section{PRE $A$ ACE}

This thesis acknowledges that the present state of housing and parks in Toronto is a result of a complex network of politics, socioeconomics, and cultures. The controversy surrounding social housing and privately owned housing significantly affects the city's housing stock. Social housing is a project in which all three levels of government are greatly invested, and in Toronto is governed by the Toronto Community Housing Cooperation $(\mathrm{TCHC})$. Privately owned buildings are often results of developers' deals with the city for land, site density, and building height variances, and as such are often political and are greatly affected by economical forces. J.B. Cullingworth writes,

Housing cannot be treated in isolation: it is inextricably inter-related with broader issues of inflation, incomes policy, income maintenance, inner city decline, and a perplexing range of difficult social and economic trends. ${ }^{4}$

Political and economic parties are also greatly invested in city parks. Toronto's collection of public parks are municipally regulated, designed, and maintained by the Parks, Forestry and Recreation Division. ${ }^{5}$ Park development and maintenance must adhere to the municipality's budget and the city's official Planning Act. In recent years, however, Toronto has begun seeking private investment to create new parks and to improve existing ones.

\footnotetext{
${ }^{4}$ J.B. Cullingworth (1979), xix quoted in John Sewell, Houses and Homes (Toronto: James Lorimer \& Company Ltd. 1994), 4. David Harvey, Fertile Ground for New Thinking: Improving Toronto's Parks (Metcalf Foundation, 2010), 16.
} 
For the purposes of this design proposal, the issues of land ownership, planning restrictions, and municipal bylaws will be overlooked during the proposed architectural intervention. The thesis concentrates more on the history and present state of towers-inthe-park, the demographics of the residents, and the theories behind their social impact. 


\section{TABLE OF CONIENIS}

Abstract

Acknowledgements

Preface

List of Illustrations

1 Introduction

1.1 Toronto's Immigration History

1.2 Toronto's Growth and the Rise of a New Housing Form

1.3 Towers in the Park and Their Residents

1.4 Park Space Below the Tower as Social Binder

2 Towers (in the Park)

2.1 The Rise of the Tower Apartment in Toronto

2.2 The Towers' Current Tenants

2.3 The Towers' Current Physical State

11-13

2.4 The Towers' Population Densities and Poverty Concentrations

2.5 The Towers' Loss of Social Gathering Spaces 
4 St. James Town, Toronto

4.1 A History of St. James Town: The Demolition of Houses

4.2 A History of St. James Town: The Rise of the Towers in the Parks

4.4 St. James Town's Deficiencies

4.5 Rehabilitating Tactics for St. James Town

36-37

4.6 Reconnecting St. James Town to the City's Streets With Parks

37-38

5 Design Precedents

5.1 Linked Hybrid - Steven Holl Architects

6 Design Proposal

6.4.1 Community Space in the Park

6.4.2 Community Space in the Towers 


\section{LIST OF TULSTRATIONS}

All images are by author unless otherwise noted

1. Conceptual Thesis Narrative

2. Conceptual Design Diagram

3. Map of Existing Tower Blocks

4. Corbusier's City of Towers

A: Le Corbusier's City of Towers plan. Retrieved from Le Corbusier translated by

Frederick Etchells, Towards a New Architecture (New York: Dover Publications Inc. 1986), 56

B: Le Corbusier's City of Towers perspective. Retrieved from Le Corbusier translated by Frederick Etchells, Towards a New Architecture (New York: Dover Publications Inc. 1986), 57.

5. Number of high-rise apartment buildings (5 storeys and higher) built in Toronto by decade. Data provided by United Way Toronto, Poverty by Postal Code2: Vertical Poverty, 30.

6. Percentage of low-income families residing in high-poverty neighbourhoods. Data provided by United Way Toronto, Poverty by Postal Code2: Vertical Poverty, 20.

7. Occurrence of Elevator breakdowns or malfunctions. Data provided by United Way Toronto, Poverty by Postal Code2: Vertical Poverty, 54.

8. Total number of repairs inside unit in the past year. Data provided by United Way Toronto, Poverty by Postal Code2: Vertical Poverty, 60.

9. Occurrence of pest infestation in the past year. Data provided by United Way Toronto Poverty by Postal Code2: Vertical Poverty, 66.

10. Number of apartment units occupied by families with more than one person per room Retrieved from United Way Toronto, Poverty by Postal Code2: Vertical Poverty, 42.

11. Percentage of family renters in high-rise apartments that are low-income by neighbourhood. Retrieved from United Way Toronto, Poverty by Postal Code2: Vertical Poverty, 39.

12. Percentage of tenants surveyed wanted improved facilities. Retrieved from United Way Toronto, Poverty by Postal Code2: Vertical Poverty, 80.

13. Frequency at which common rooms are used. Data provided by United Way Toronto, Poverty by Postal Code2: Vertical Poverty, 76.

14. Availability of common rooms or recreational facilities. Data provided by United Way Toronto, Poverty by Postal Code2: Vertical Poverty, 76. 
15. Types of support provided by others in the building. Data provided by United Way Toronto, Poverty by Postal Code2: Vertical Poverty, 118.

16. Conceptual High-rise Housing Diagram

17. Figure 15: High-rise tenants' assessment of their neighbourhood. Data provided by United Way Toronto, Poverty by Postal Code2: Vertical Poverty, 160.

18. Conceptual Park Diagram

19. Existing Building Conditions in St. James Town

20. Existing St. James Town Site Aerials

21. Newspaper article depicting block busting tactics. Image by Mario Geo (13 April, 1971) Retrieved 14 October, 2013 from http://urbantoronto.ca/forum/showthread.php/6947Miscellany-Toronto-Photographs-Then-and-Now/page126

22. St. James Town Site Historic Plans

A: St. James Town neighbourhood plan before 1960. Retrieved from John Sewell, The Shape of the City: Toronto Struggles with Modern Planning (Toronto: University of Toronto Press, 1993), 164.

B: St. James Town neighbourhood plan after development in 1970. Retrieved from John Sewell, The Shape of the City: Toronto Struggles with Modern Planning (Toronto: University of Toronto Press, 1993), 165.

23. Billboard advertising St. James Town to young professionals, 1970. Retrieved from City of Toronto Archives, Series 374, File 1048-2

24. Fences dividing adjacent buildings, 2013

25. Grocery store abandoned on Sherbourne Street, 2014

26. Perspective of park from sky bridge. Image by Iwan Baan retrieved 28 January, 2014 from http://www.archdaily.com/34302/linked-hybrid-steven-holl-architects/

27. Perspective of pond from ground plane. Image by Iwan Baan retrieved 28 January, 2014 from http://www.archdaily.com/34302/linked-hybrid-steven-holl-architects/

28. Plan of linked programs with sky bridges. Image by Steven Holl Architects retrieved 28 January, 2014 from http://www.archdaily.com/34302/linked-hybrid-steven-hollarchitects/

29. Roof plan showing green roofs and landscaping. Image by Steven Holl Architects retrieved 28 January, 2014 from http://www.archdaily.com/34302/linked-hybrid-stevenholl-architects/

30. Landscape plan showing entrances from the street. Image by Steven Holl Architects retrieved 28 January, 2014 from

http://www.floraw.com/data/file/collection//files/attach/images/452296/809/724/125235 5397-urban-porosity-1000x639.jpg 
31. Perspective of theatres on ground plane. Image by Shu He retrieved 28 January, 2014 from http://housevariety.blogspot.ca/2011/02/linked-hybrid-by-steven-hollarchitects.html\#.U01iifldV8E

32. Site aerial of red segment of park. Image by Bjarke Ingels Group retrieved 23 January, 2014 from http://felizarquitectura.files.wordpress.com/2013/06/superkilen.jpg

33. Night Perspective of red segment. Image by Bjarke Ingels Group retrieved 23 January, 2014 from http://www.archdaily.com/286223/superkilen-topotek-1-big-architectssuperflex/

34. Boxing ring. Image by Bjarke Ingels Group retrieved 23 January, 2014 from http://www.archdaily.com/286223/superkilen-topotek-1-big-architects-superflex/

35. Custom slide and play structure. Image by Bjarke Ingels Group retrieved 23 January 2014 from http://www.archdaily.com/286223/superkilen-topotek-1-big-architectssuperflex/

36. Seating in black segment. Image by Bjarke Ingels Group retrieved 23 January, 2014 from http://www.archdaily.com/286223/superkilen-topotek-1-big-architects-superflex/

37. Jungle gym. Image by Bjarke Ingels Group retrieved 23 January, 2014 from http://www.archdaily.com/286223/superkilen-topotek-1-big-architects-superflex/

38. Landscape of red, black, and green, portions of the park. Image by Bjarke Ingels Group retrieved 23 January, 2014 from http://www.archdaily.com/286223/superkilen-topotek1-big-architects-superflex

39. Thesis Conceptual Design Narrative

40. Schematic Planning Narrative

41. Site Development Phasing Plan

42. Before and After of St. James Town Facade

43. Typical 3-Bedroom Unit Rehabilitation Schematic Diagram

44. New Landscape Plan

45. New Landscape Connector Zones

46. Location of New Programs

47. St. James Town New Community Park Space During Summer

48. St. James Town New Community Park Space During Winter

49. St. James Town New Sherbourne Street Retail Strip

50. Building Sections Through Towers and Parks 


\section{१.(0) INIROLCIION}

FIG. 1

Conceptual Thesis Narrative

A. Towers in the Park

B. The divorce of towers from parks

C. Precedent analysis of tower and park projects

D. Re-marriage of rehabilitated towers and parks

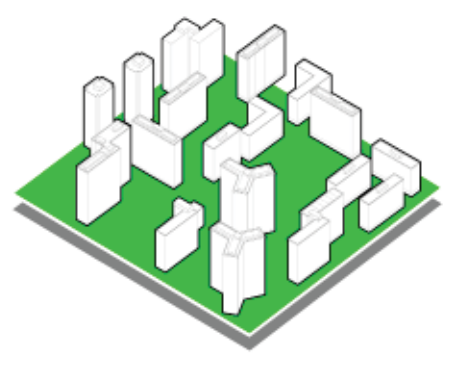

The objective of this thesis and its associated design project is to determine the architectural factors that will foster a more holistic communal atmosphere in addition to providing better living conditions for the residents of these towers-in-the-park neighbourhoods. First, this thesis conceptually divorces the union of towers and parks into individual elements. This decoupling will allow for a specific analysis of each entity and its respective history, social significance, and urban importance. Secondly, this thesis examines St. James Town, Toronto's first towers-in-the-park community and presently Canada's most densely populated neighbourhood. Thirdly, this thesis investigates exemplary projects of urban housing and urban parks to identify possible strategies and hindrances to urban renewal. Last, this thesis designs a proposal for the site which remarries the tower and parks and carries forward their respected theories examined in previous sections. The design becomes a microcosm of the city.

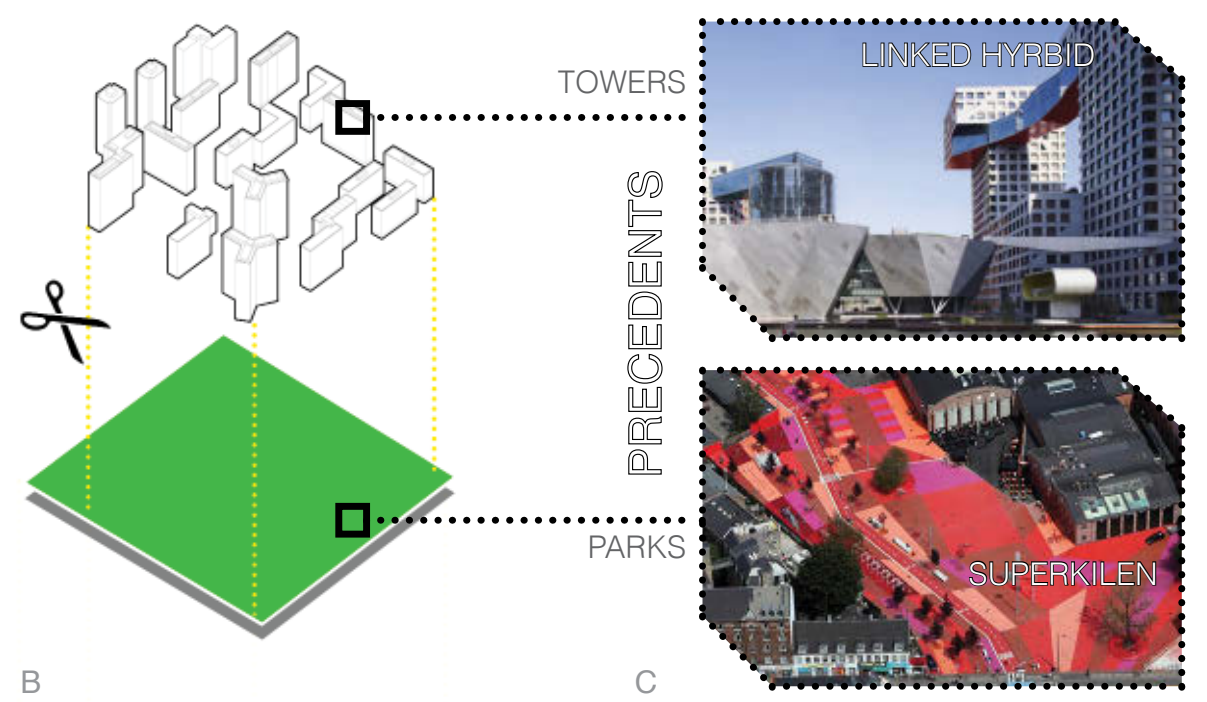

D

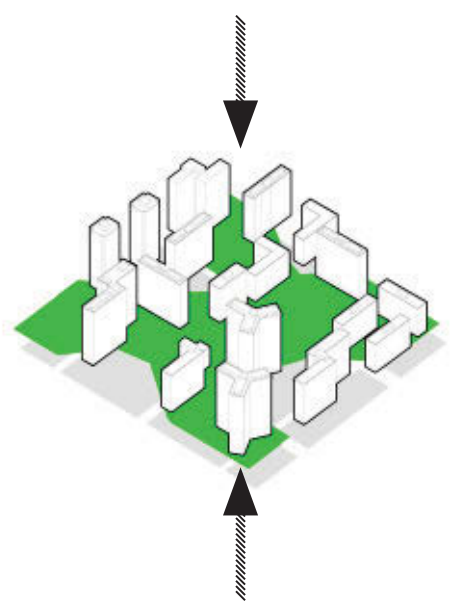




\subsection{TORONTO'S IMMIGRATION HISTORY}

Toronto is a multicultural city known for being a hub for commerce and trading. It is the largest city in Canada, populated by just shy of 2.8 million residents. As the fourth largest city in North America, Toronto just surpasses Chicago and falls behind Mexico City, New York, and Los Angeles. Since 49 per cent of the city's population was born outside of Canada, Toronto can be defined as one of the most diverse cities in the world. ${ }^{6}$ The growth of Toronto as a city is largely attributed to its immigration history. Following World War II, a large number of refugees from war-torn Europe arrived along with Chinese immigrants. The gradual elimination of racially based immigration policies combined with the establishment of the Immigration Act of 1976 made Canada more appealing to newcomers. ${ }^{7}$ Presently, Canadian immigration rates remain high, and Toronto welcomes the entry of approximately 55,000 new immigrants each year. ${ }^{8}$

\subsection{TORONTO'S GROWTH AND THE RISE OF A NEW HOUSING FORM}

Toronto's population spiked from 1.0 million in 1951 to two million by 1971 . Forty years since then, the city's population has only grown to 2.8 million people. Conversely, the Greater Toronto Area (GTA), which encompasses the city as well as numerous surrounding suburbs and townships, has grown to a population of over 6 million

\footnotetext{
${ }_{6}^{6}$ City of Toronto, Toronto's Racial Diversity, 2013, http://www.toronto.ca/toronto facts/diversity.htm, 3 February 2014. 7 Canada: Immigration Act, 1976-77, c. 52, s. 1, National Legislative Bodies, 1976,

http://www.refworld.org/docid/3ae6b5c60.html, 3 February 2014.

Toronto's Racial Diversity, 2013, http://www.toronto.ca/toronto facts/diversity.htm, 3 February 2014.
} 
according to Canada's 2011 Census. $^{9}$ The evolution of the GTA from a collection of rural farmland to a metropolis of 6 million was greatly due to the large-scale suburbanization that was initiated in the 1950s. It is also during this time period that Toronto sought a housing alternative to combat the large-scale suburbanization. This alternative took the shape of the towers-in-the-park design, which Le Corbusier created for Paris after the Second World War. ${ }^{10}$ This modern design, comprised of tall towers set in the middle of a lush green park, was adopted to lure the middle class back to the city. At first, these towers were marketed to and populated by the middle class, but soon that targeted population moved out to the suburbs, leaving a void that was quickly filled by newly arrived immigrant residents who made these towers their first home in Canada.

\subsection{TOWERS IN THE PARK AND THEIR RESIDENTS}

The majority of these towers are approaching or exceeding 40 years of age. They were built in the 1960s to respond to the influx of new immigrants and the spike in the city's population, but after several decades have become energy inefficient and fallen into disrepair. ${ }^{11}$ Although much of the high-rise rental stock was originally designed for middleincome households, it now appears to be predominantly housing the city's low and moderate income families, most of whom are new immigrants. While the migration of low-income newcomer families to this form of housing may contribute to the geographical

\footnotetext{
${ }^{9}$ Ontario Population Projections Update, Ontario Ministry of Finance, Spring 2013, http://www.fin.gov.on.ca/en/economy/demographics/projections/, 21 February 2014.

${ }^{10}$ John Sewell, The Shape of the City: Toronto Struggles with Modern Planning (Toronto: University of Toronto Press, 1993), 170.

1 John Sewell, Houses and Homes (Toronto: James Lorimer \& Company Ltd. 1994), 54.
} 
concentration of poverty, it is still crucial to preserve this housing stock so that the city can provide decent housing to all households regardless of income. High-rise buildings have also become more densely populated because oftentimes more than one person or even family occupies a single bedroom, putting more pressure on aging building infrastructure and systems. ${ }^{12}$

There is a strong matrix of camaraderie and mutual support among many high-rise tenants; however, the creation of a larger community atmosphere within the buildings is severely compromised by the lack of social space. Nearly half of all the privately owned apartment buildings no longer have any kind of common room or recreational space for tenant use. In places where they do exist, they are designed for a broad range of purposes including familial, communal, and cultural events. In a report by the United Way Toronto, residents spoke passionately about the importance of such spaces. These spaces have the capacity to promote active living and foster a sense of community, features that are especially important for children and youth. The residents also spoke of the role these spaces play in reducing social isolation and distrust among neighbours. ${ }^{13}$ For many tenants, the loss of common space means the loss of community; it is clear that shared space brings a community to life.

The architecture of these towers-in-the-park is often thought of as the catalyst for poor living conditions. However, a case can be made that it is the lack of social networks within

\footnotetext{
${ }^{12}$ United Way Toronto, Poverty by Postal Code2: Vertical Poverty (Toronto, Ontario: United Way, 2013), iii.
${ }^{13}$ Ibid, vii.
} 
these buildings that are in fact the contributors to their demise. Community networking and mingling create a need for greater gathering spaces, which the buildings in their current state cannot fulfil. A large number of newcomers want to socialize with their neighbours, especially those with whom they share common origins, languages, and/or cultural practices but are unable to do so because of the lack of facilities within the building. The lack of and deterioration of these programmed common spaces deprive the buildings of a sense of community.

\subsection{PARK SPACE AT THE BASE OF THE TOWERS AS SOCIAL BINDER}

High-rise apartments can provide high quality family homes if they can establish adequate social spaces for the residents. The "Park" in the moniker of these Towers-in-the-Park is often a poorly maintained and rarely used patch of lawn. The GTA is expected to increase by more than forty-four percent to an estimated 9.2 million people in the next thirty years. ${ }^{14}$ This population growth will increase the density within the city of Toronto, emphasizing the need for parks to effectively serve as urban gathering spaces. The problem, however, is that the city has already maximized its inventory of parks and has started selling off park space for private developments. ${ }^{15}$ This downgrading will widen the gap between the supply and demand of parks. A possible solution to this problem is to

\footnotetext{
${ }^{14}$ Niamh Scallan, Density Toronto: As GTA population rises, so do expectations for denser living, The Toronto Star, 19 October 2012, http://www.thestar.com/news/gta/2012/10/19/density_toronto_as_gta_population_rises_so_do_expectations_for_denser_living.html 12 November, 2013.

David Harvey, Fertile Ground for New Thinking: Improving Toronto's Parks (Metcalf Foundation, 2010), 18.
} 
FIG. 2

Conceptual Design Diagram

The interconnection of housing, parks, and amenities to become a microcasm of the city use the tower's private park space as an arena for public and social programs. This conversion can plant the seeds of community into the vast swaths of underutilised land surrounding these towers. A new landscape design transforming the poorly utilized space below a building can address the tower residents' and city residents' needs for social space and community cohesion.

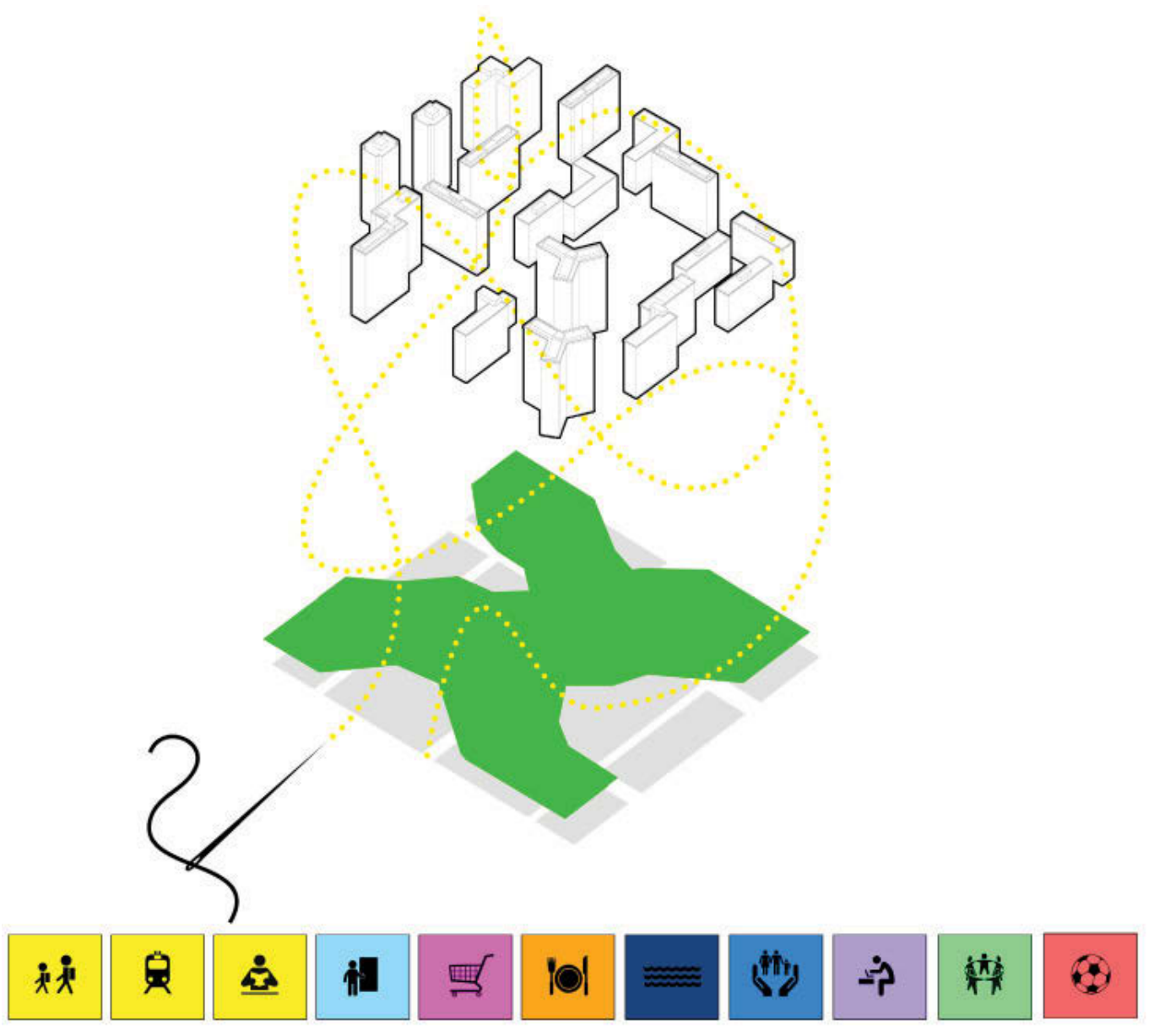




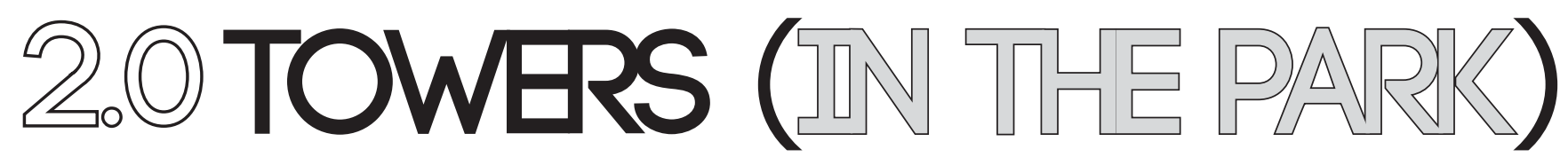

This chapter first discusses the history of the high-rise rental apartment in Toronto as a means of understanding the city's growth. It then examines the forces that have led to the changes in demographics of these vertical communities and the needs of its current residents. This section then analyzes the physical state of the buildings, including the typical lifelines of the buildings' systems and tenants' request for repairs. Further along, this section looks at the internal forces that socially and physically place stresses upon the buildings. Last, this chapter argues for the towers' public reintegration and its significance to the 1 million people of Toronto who inhabit them as well as to Toronto's housing stock.

Map of Existing Tower Blocks

Locations of Towers-in-the-Park communities in Toronto in relation with transit routes

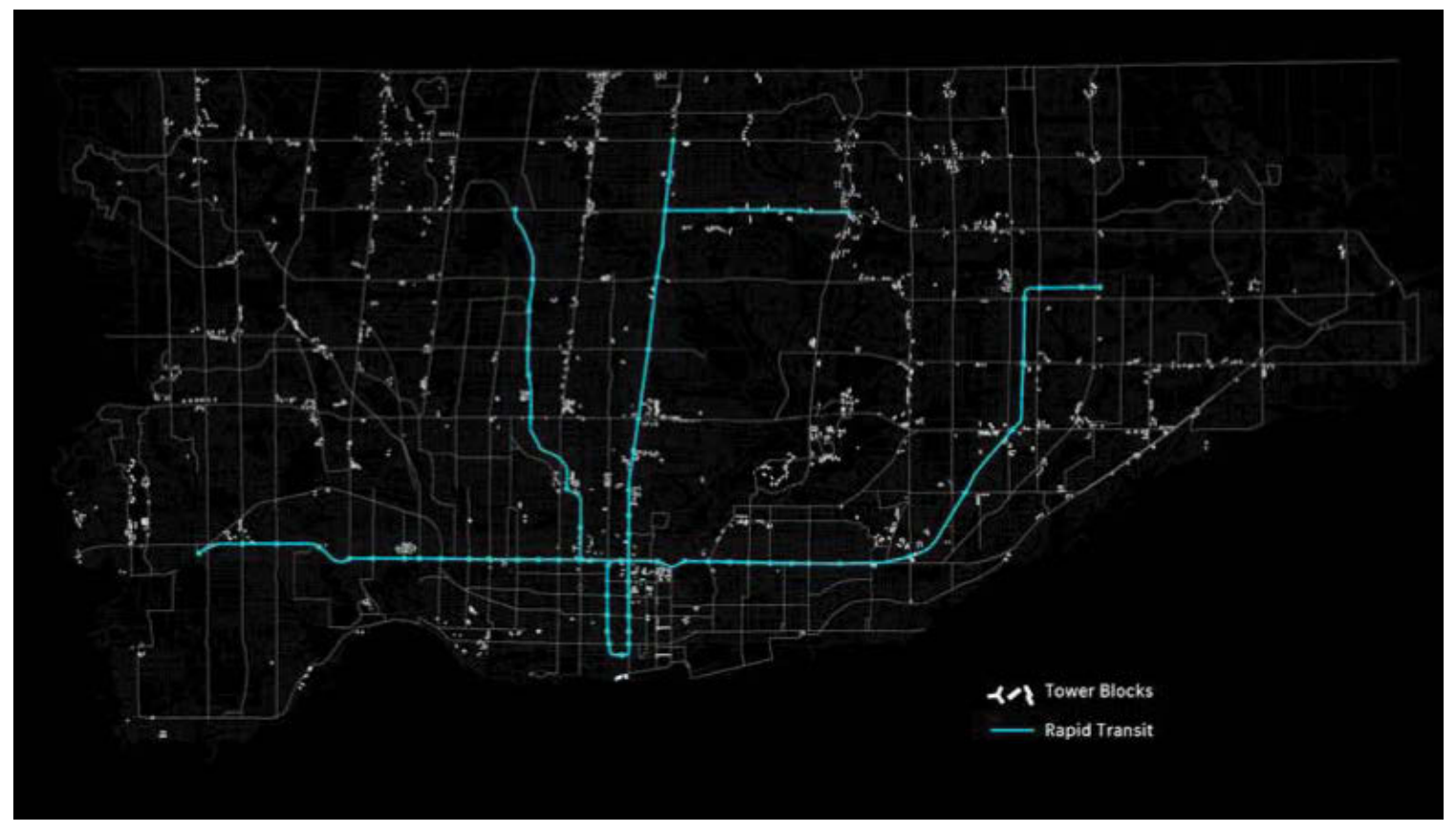




\subsection{THE RISE OF THE TOWER APARIMENT IN TORONTO}

The GTA has 2,000 high-rise residential buildings. ${ }^{16}$ Toronto alone contains half of those buildings totalling approximately 1,000 high-rise apartments. These structures provide homes for upwards of 1 million residents in the GTA, most of who are low-to-middle income immigrants. That number is higher than the total population of Ottawa - Canada's fourth largest city. These emblems of urban living have come to be colloquially known as city ghettoes, but in order to understand the present state of the buildings, one must first grasp their history.

These towers-in-the-park were adopted from Le Corbusier's plan for a "City of Towers" in 1920. During this time, Le Corbusier says, "The great towns have become too dense for the security of their inhabitants and yet they are not sufficiently dense to meet the needs of modern business." 17 In an attempt to remedy the noise, fumes, and dust from the congested streets of the city, Corbusier proposed the construction of buildings that would rise 60 storeys and be made of reinforced concrete and steel. ${ }^{18}$ These towers were designed to sit in the middle of a city block away from the busy streets and would be distanced 500 to 600 feet away from one another. The height and distance between the towers would allow fresh air, light, and uninterrupted views to flood the apartments. The grounds between neighbouring towers would be filled with gardens and fields for children

to play. These picturesque parks would provide shelter from the commotion of the city,

\footnotetext{
${ }^{16} \mathrm{~A}$ high-rise apartment building in Ontario is classified as being 5 stories or higher.

${ }^{17}$ Le Corbusier translated by Frederick Etchells, Towards a New Architecture (New York: Dover Publications Inc. 1986), 57

${ }^{18}$ Kenneth Frampton, Modern Architecture: A Critical History, 4th ed. (London: Thames and Hudson Ltd. 2007), 155.
} 

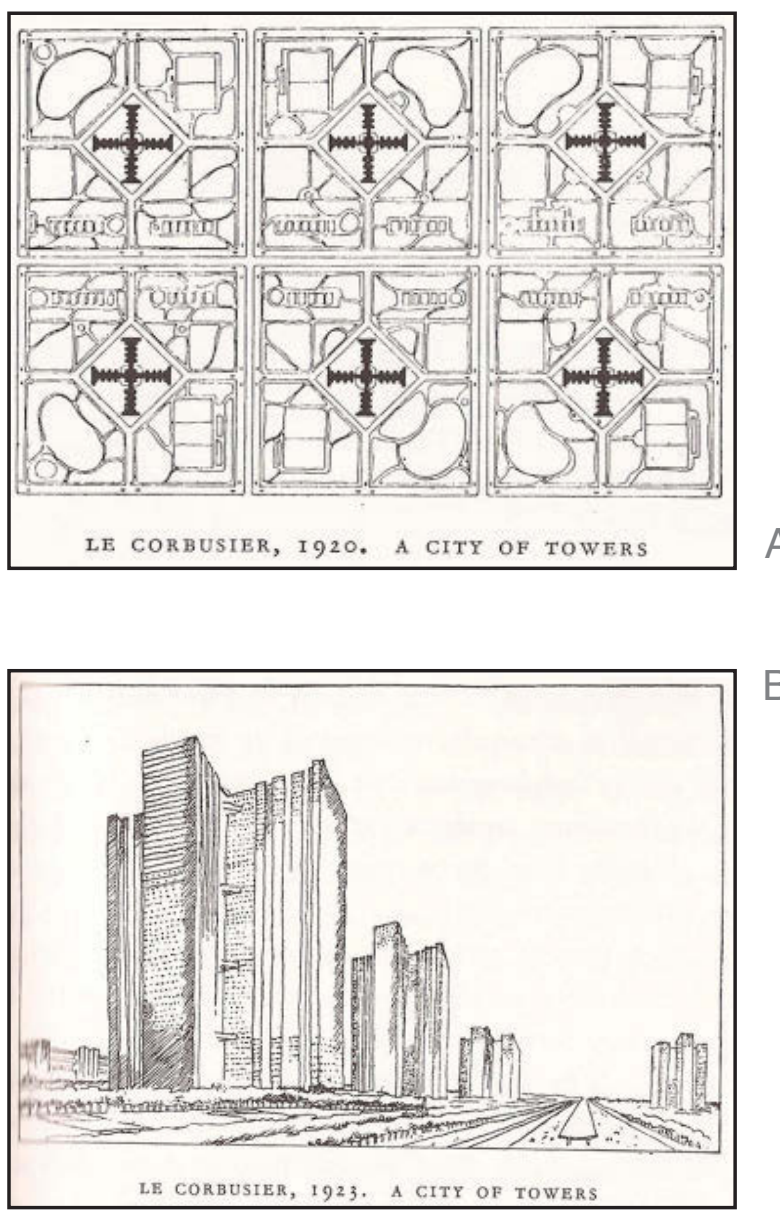

FIG. 4

Corbusier's City of Towers

B. Le Corbusier's City of Towers Perspective

and the towers would provide a means to achieve greater density for the modern city. ${ }^{19}$ Corbusier's proposal for a city of towers seemed to have resolved the prevailing issues that faced the city at the time.

Le Corbusier's tower solution seemed ideal for rebuilding parts of Europe devastated by WWII. It was also during this time, following the War, that Canadian cities changed from a largely rural economy to an urban one. City populations also boomed. Toronto grew from a population of 1.0 million in 1951 to 2.0 million by $1971 . .^{20}$ The 1950 s through to the 1970s signalled a change in the way cities looked, felt, and functioned correlating with both suburbia and high-rise towers. Due to new housing policies and nationally-backed mortgages, the middle class were able to afford newly built houses on large lots beyond the city's core. This was the beginning of the GTA's growth, which now has a population of over 6.0 million. ${ }^{21}$

In an attempt to combat the middle class's exodus from the city, Toronto officials rezoned areas for redevelopment at the beginning of the 1960s. In so doing, they promoted a new form of housing, and specifically to towers-in-the-park in Canada. Planners looked to the residential high-rise construction in Europe and adopted its practice in Toronto. The 1960s in Toronto saw the building of 730 apartment buildings, all of which were at least

\footnotetext{
${ }^{19}$ Le Corbusier, 56-58.

${ }^{20}$ Population estimates for Toronto, Canada, 1950-2015, http://books.mongabay.com/population_estimates/full/Toronto-Canada.htm/, 25 February 2014.

${ }^{21}$ Ontario Population Projections Update, Ontario Ministry of Finance, Spring 2013,

http://www.fin.gov.on.ca/en/economy/demographics/projections/, 21 February 2014.
} 


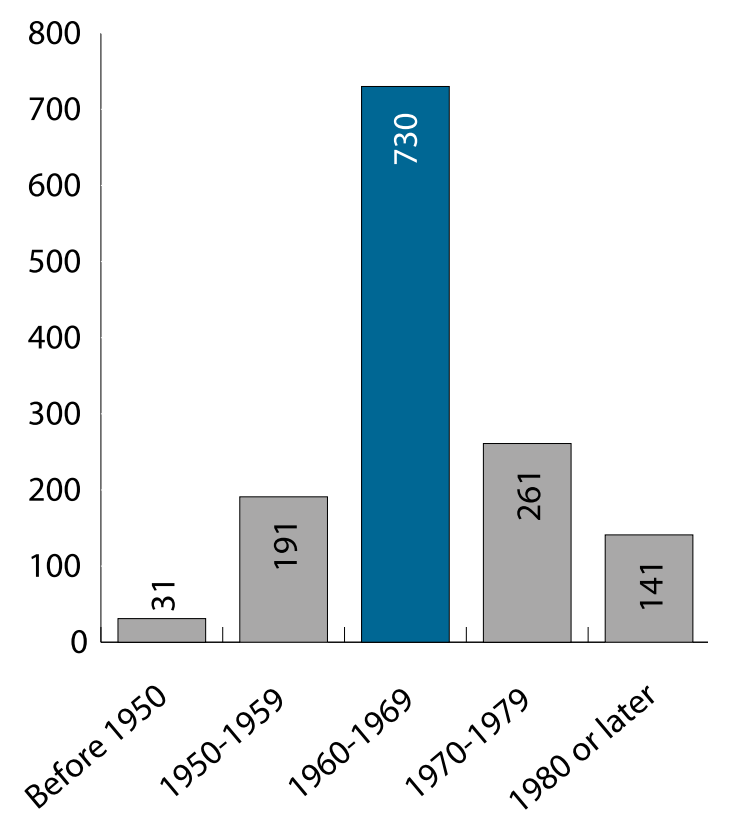

FIG. 5

Number of High-rise Apartment Buildings (5 Storeys and Higher) Built in Toronto by Decade five storeys. 22 John Sewell writes, "While suburbia was being built, older parts of the city were demolished and replaced with high-rise towers surrounded by unused grass."23 These new towers were marketed to the middle class in order to lure them back to the city. The appeal was a new, trendy lifestyle that included many amenities such as swimming pools, theatre rooms, and park space closer to the heart of the city. The middle class, especially young professionals, were initially drawn to these towers but eventually decided to opt for the suburbs, as explained below, thus vacating these structures. The transience of the middle class in this housing vernacular allowed a new demographic in Toronto to enter.

\subsection{THE TOWGR'S CURRENT TENANTS}

The attractions of suburbia and home ownership were too strong and ultimately caused the Canadian-born middle class to depart from the towers. During the 1960s, Canada underwent a housing reform and a reshaping of their housing stock. Towers were being built in cities while suburbia continued to expand. At the same time, Canada also made reparations in its immigration policy that subsequently led to the Immigration Act of 1976. This legislation eliminated racially based criteria for new immigrants. ${ }^{24}$ According to the City of Toronto's website, the city welcomes a quarter of all new Canadian immigrants; this amounts to 55,000 people annually. Toronto has accepted over a million immigrants

\footnotetext{
${ }^{22}$ City of Toronto, Tax Assessment Files, 2009 as quoted in United Way Toronto, Poverty by Postal Code2: Vertical Poverty (Toronto, Ontario: United Way, 2013), 30.

${ }^{23}$ John Sewell, Houses and Homes, 13.

${ }^{24}$ Canada: Immigration Act, 1976-77, c. 52, s. 1, National Legislative Bodies, 1976, http://www.refworld.org/docid/3ae6b5c60.html, 3 February 2014.
} 


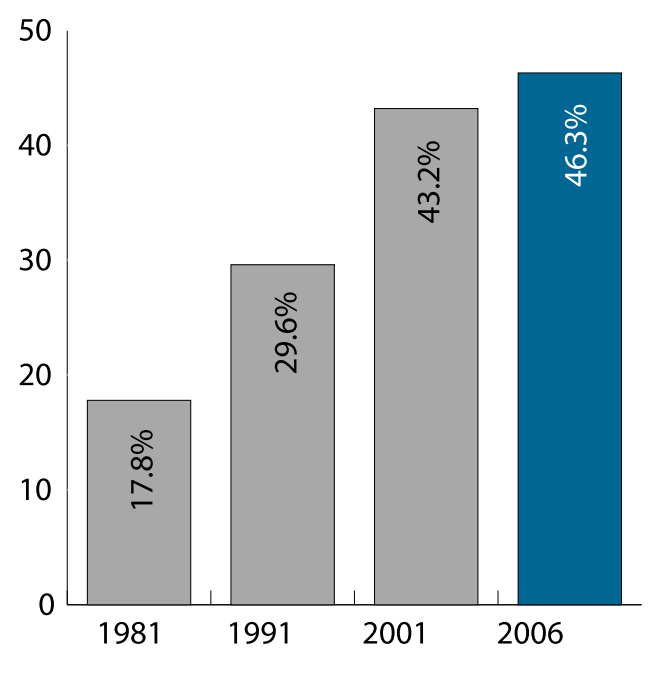

FIG. 6

Percentage of Low-Income Families Residing in High-Poverty Neighbourhoods since 1960 and today boasts a total immigrant population of 1,237,720 which is roughly half of the city's total population. ${ }^{25}$ A large number of these immigrants have taken to these towers as their first home in Canada due to the relatively cheap rents. About 1 million people call these vertical villages home in the GTA with over 74 percent being immigrants. ${ }^{26}$ Many of these inhabitants are categorized as "low-income," 27 proving a discrepancy between those for whom the towers were originally intended and those who now actually live in them. The United Way described these tower communities as examples of "vertical poverty." Forty percent of all families living in these tower apartments were reported to fall in the low-income threshold in 2006 a figure that is up 20 percent since $1981 .{ }^{28}$ The concentration of poverty in these vertical communities is growing each year as the buildings age.

\subsection{THE TOWER'S CURRENT PHYSICAL STATE}

In the three decades between the beginning of the 1950s to the end of the 1970s, Toronto gained 1,300 high-rise apartments containing over 200,000 individual units. ${ }^{29}$ Much like the original scheme by Le Corbusier, these towers' structural frames were made of poured reinforced concrete and cladded with non-bearing brick curtain wall

\footnotetext{
${ }^{25}$ City of Toronto, Toronto's Racial Diversity, 2013, http://www.toronto.ca/toronto_facts/diversity.htm, 3 February 2014. ${ }^{26}$ Brendan Kennedy, Over a million living in highrises have been largely ignored, 05 December 2010, http://www.thestar.com/news/gta/2010/12/05/over_a_million_living_in_highrises_have_been_largely_ignored.html, 15 January, 2014

${ }^{27}$ In Toronto, a 4 person family with a gross household income of $\$ 27,500$ or less is considered low-income. Statistics Canada, Low Income Cut-offs, 2 May 2013, http://www.statcan.gc.ca/pub/75fo002m/2012002/lico-sfr-eng.htm, 15 January, 2014. United Way Toronto, Poverty by Postal Code2: Vertical Poverty (Toronto, Ontario: United Way, 2013), V. ${ }^{29} \mathrm{lbid}, 51$
} 

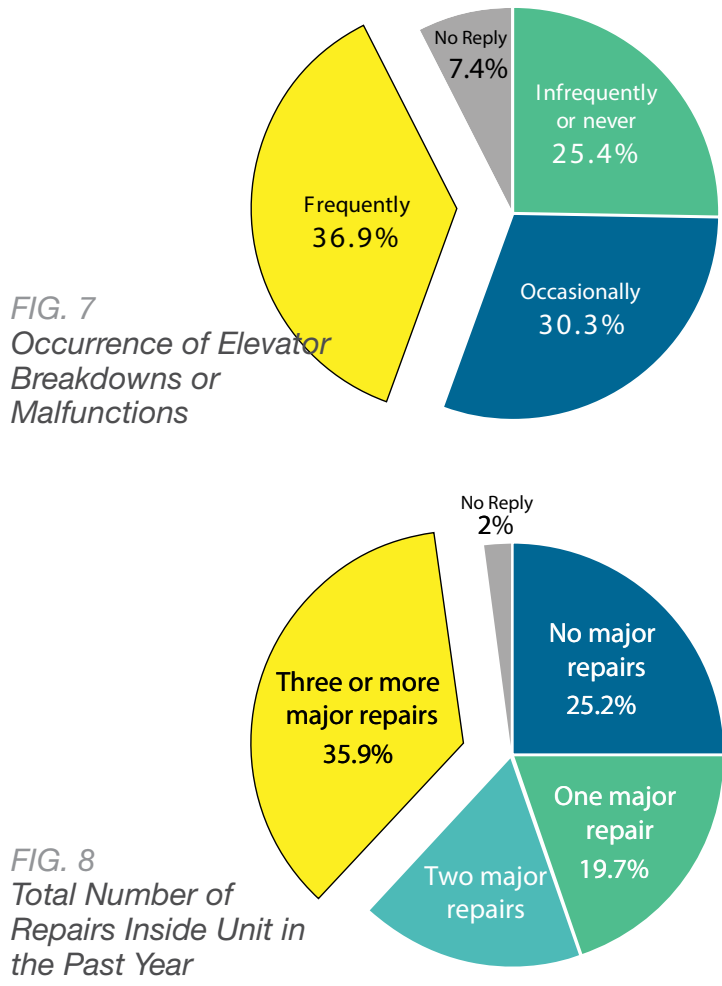

the Past Year

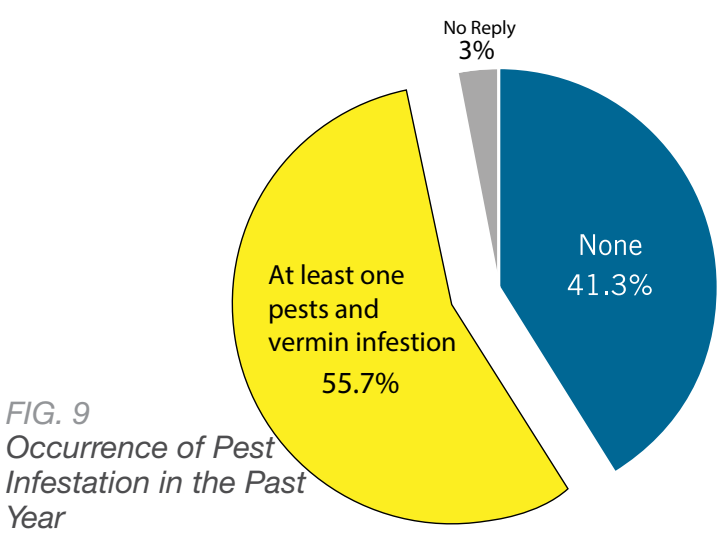

systems. ${ }^{30}$ Some of these towers are now reaching forty years of age which means that their building systems have begun to or have already deteriorated. The skeletal concrete frame was constructed to last up to 100 years. The structural system is thus still considered functional and in good shape; however, the heating, ventilation, and cooling systems have reached their 20 to 25 year lifeline. Additionally, the electrical systems are also nearing their expiration date. Landlords often do not have the funds to support retrofits for aging systems or to conduct major repairs due to rent controls by the municipal government. This deficiency has forced some of these building into further disrepair.

In its Vertical Poverty report, The United Way surveyed over 2,800 tenants across Toronto about the physical state of their buildings. Frequent elevator breakdowns are a frustrating happenstance for many residents who have to wait upwards of 10 minutes for the elevator or who end up climbing numerous flights of stairs. The building envelope is also a major concern since weather penetrates through roofs and walls. Residents report that their units are extremely cold in the winter and are extremely hot in the summer. Balconies have started to crumble and railings have become dislodged. Damages to common areas are rarely tended to, which leaves the floors, ceilings, and walls in recreation rooms in poor states. Necessary repairs within the individual units include the retiling of bathroom floors, and the replacement of plumbing hardware, countertops, cupboards, and fire alarm systems. The overall maintenance and cleanliness of these

${ }^{30}$ John Sewell, Houses and Homes, 54. 
buildings are also a concern, as a large number of tenants reported the presence of pests and vermin. ${ }^{31}$
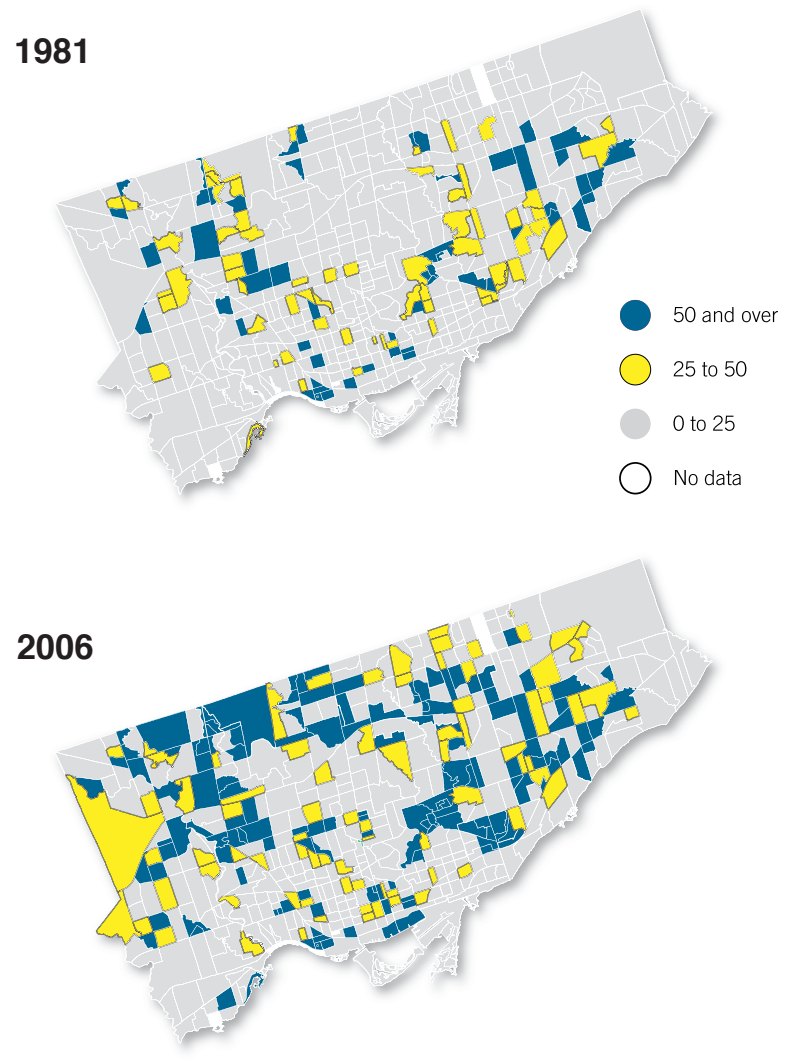

FIG. 10

Number of Apartment Units Occupied by Families With More Than One Person Per Room

\subsection{THE TOWER'S POPULATION DENSITIES AND POVERTY CONCENIRATIONS}

The erosion of Toronto's high-rise rental towers can be attributed to the increasing household densities within these vertical communities. This increase of residents in the buildings places added strain upon elevators, garbage systems, water supply systems, and electrical systems as well as general repairs and maintenance. The rise in the population of these towers causes a parallel rise in the demands of the buildings' systems and services. Based on census data, 8 percent of 9,475 units were occupied by families with more than one person per room in 1981. That figure has risen to 17 percent of 24,240 units in $2006 .{ }^{32}$ The practice of multiple families cohabitating in a individual unit is common, especially amongst newcomer families.

These families come to live in one dwelling for two reasons: support of kinship and income sharing. There is a widening income gap between the rich and poor in the city. Based on the most recent census, Toronto boasts the second highest average household income of any metropolitan area in Canada, however, the average renter household

\footnotetext{
${ }_{32}^{31}$ United Way Toronto, Poverty by Postal Code2: Vertical Poverty (Toronto, Ontario: United Way, 2013), 53-71.
} 

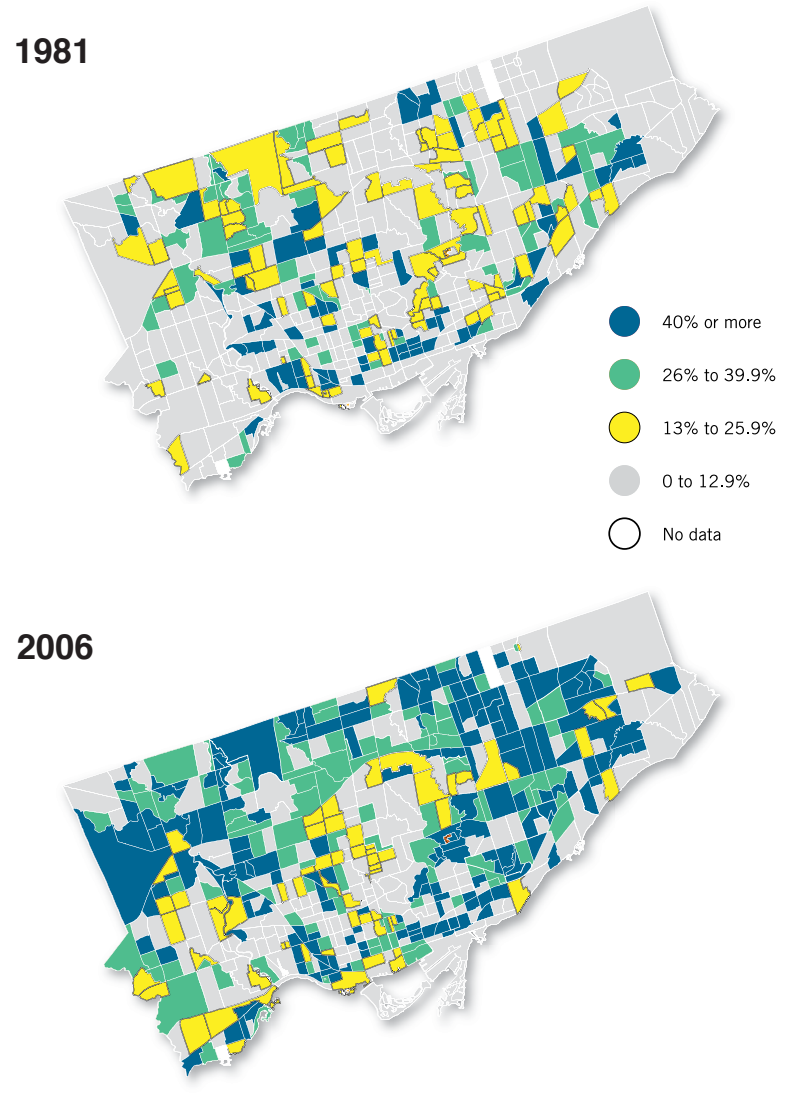

FIG. 11

Percentage of Family Renters in High-rise Apartments That Are Low-Income by Neighbourhood income has dropped to 33,397 dollars in 2006 from 39,793 dollars in $1981 .^{33}$ Inflation caused the cost of living to increase, but the average income of these residents decreased. This disparity puts pressure on families to share apartments to make ends meet.

A possible remedy to the growing problem of income polarization is the restoration of mixed-income neighbourhoods. Three decades ago, low-income families could find housing in most parts of Toronto and live in neighbourhoods alongside high-income families. $^{34}$ Municipal governments value the middle-to-upper class because of the taxes that this demographic provides. This often leads to efforts to appease this population with regular city services that are not extended to poorer communities. The concentration of low-income households in tower communities allow them to be easily neglected or forgotten by the city and the landlords. Low-income households often cannot afford to put equity into their property leading to a downward spiral of degradation. Income mixing of households can provide a balance of equity in a neighbourhood. This mingling could take the form of a rehabilitation effort where rental properties are mixed in with condominium units and vice versa. The design of such a retrofit should include multiple apartment and condominium types catering to a wide array of households from the single dweller to large and multiple families. Architecture can provide the foundation for mixedincome neighbourhoods but help is also required from the city. A proposed policy can be made to have the city offset maintenance fees of a rental unit to match the maintenance 

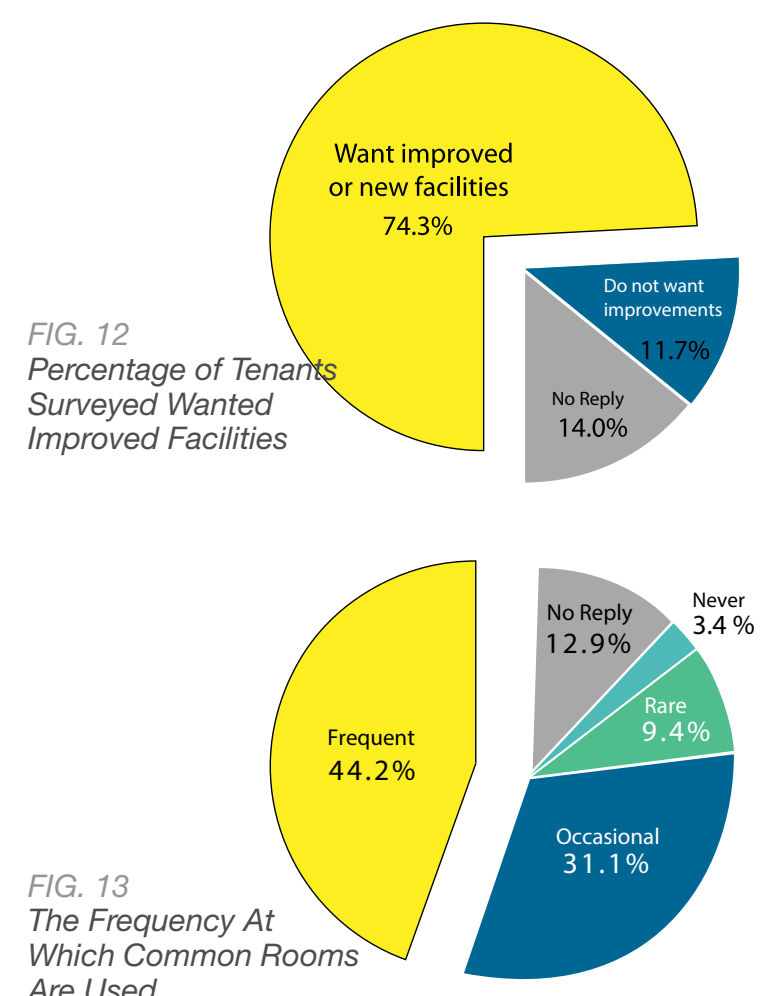

Are Used

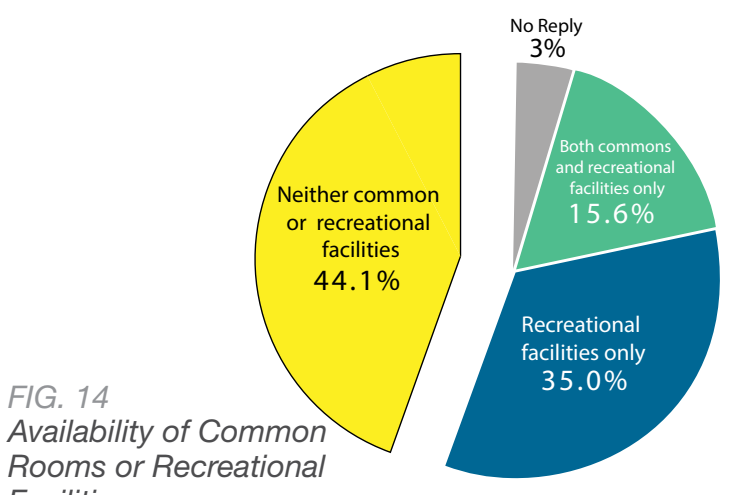

Rooms or Recreationa

Facilities fee of condominium owners. This maintenance reserve can be used for repairs and general upkeep of the buildings. In order to create mixed-income neighbourhoods and have them be successful takes dedication from both the public and private sectors.

\subsection{THE TOWER'S LOSS OF SOCIAL GATHERING SPACES}

The population within a cluster of high-rise towers can rival that of a small town. The towers were originally equipped with amenities, recreation, and common spaces that would promote a community atmosphere. The buildings once offered swimming pools, saunas, tennis courts, lounges, activity rooms, and spacious lobbies. These features were marketed to the young professionals at the time, but since with the decrease of tenants' incomes and with more families and new immigrants populating the buildings the amenities have disappeared and the density of the buildings has increased along with the poverty concentration. The United Way Toronto stated:

With more families and more children in high-rise buildings, and more households which lack financial means to access social and recreational facilities outside of the immediate neighbourhood, onsite amenities and recreational spaces have never been so important. More than a marketing feature, they now play a fundamental role in supporting family and community life. ${ }^{35}$

${ }^{35}$ United Way Toronto, Poverty by Postal Code2: Vertical Poverty, 74. 


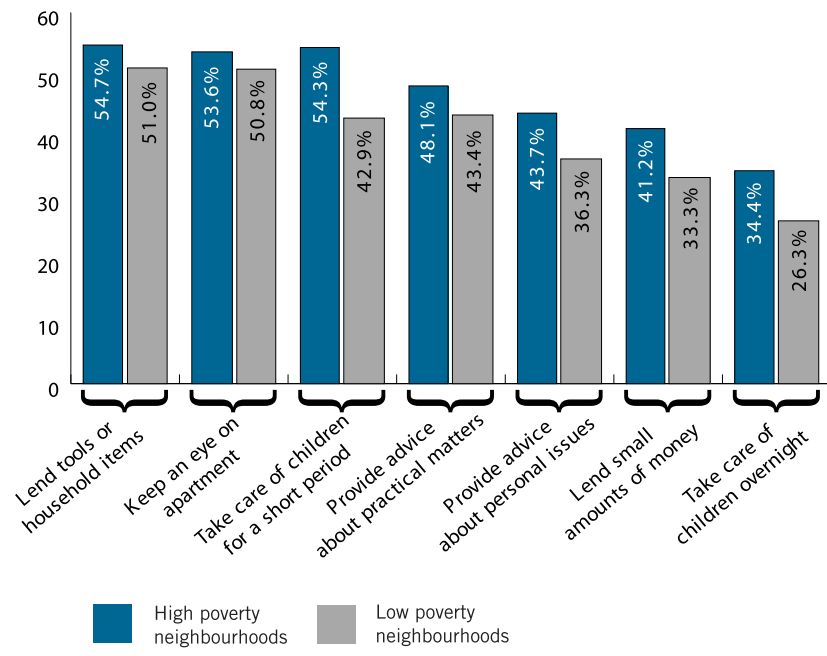

FIG. 15

Types of Support Provided by Others in the Building
The importance of these spaces for the health of the community is now paramount, but the Tower Renewal Unit at the City of Toronto argues that these spaces have slowly disappeared due to cost of maintaining and repairing them over the past few decades. The audit also shows that half of private-sector apartment buildings have no social or recreational spaces at all for tenant use, and those that exist are in poor condition. Tenants who had access to common rooms and recreational areas said that the spaces were used regularly for a range of family, cultural, and community events. The possibilities of these on-site common spaces to promote interaction between neighbours, participation of community activities, and safe play for children demonstrate the spaces' immense value. The tenants spoke about how common areas can turn a building into a real community, where neighbours know each other and look out for one another's children. The tenants who did not have access to these communal spaces talked about feelings of isolation and mistrust amongst neighbours. ${ }^{36}$ The availability of community spaces within these apartment buildings greatly fosters a holistic community environment.

Social capital is an intangible concept that refers to a system of social relationships that symbiotically benefits individuals, social groups, and society at large, thus it is a critical component of healthy and strong communities. ${ }^{37} \quad$ A community's positive social capital signifies connections between neighbours, friends, and family, all of which contribute to a friendly neighbourhood atmosphere. The participation in community events helps reinforce social bonds and promotes community spirit that provides valuable support and

${ }^{36}$ United Way Toronto, 81.

${ }^{37}$ Andrea A. Anderson and Sharon Milligan, "Social Capital and Community Building", in Community Change: Theories, Practice, ad Evidence, edited by Karen Fulbright-Anderson and Patricia Auspos (Washington D.C.: The Aspen Institute, 2006). 
opens up social and economic possibilities. Common ties such as religion, homelands, and language are important parts of friendships in such apartment buildings. All of these social bonds are facilitated by access to community spaces within the towers.

\title{
2.6THE TOWERS MOVE INTO HANNA ARENDTS PUBLIC \\ REALM
}

Hannah Arendt, social theorist, philosopher, and author of The Human Condition, writes that human life can be divided into two realms of existence: the public realm and the private realm. ${ }^{38}$ Arendt calls the public realm as "The Common" and argues,

\begin{abstract}
Only the existence of a public realm and the world's subsequent transformation into a community of things which gathers men together and relates them to each other depends entirely on permanence. If the world is to contain a public space, it cannot be erected for one generation and planned for the living only; it must transcend the lifespan of mortal men. ${ }^{39}$
\end{abstract}

The public realm to Arendt is a sphere in which action takes place for the betterment of society. It is in direct opposition to the private realm, which she termed "Property". ${ }^{40}$ For Arendt, the private realm was where self-sustaining behaviours and activities pertaining to human survival took place. This was the realm of necessity in which she included housing

\footnotetext{
${ }^{38}$ Hannah Arendt, The Human Condition (Chicago: University of Chicago Press, 1998), 50. ${ }^{39} \mathrm{Ibid}, 55$.

${ }^{40} \mathrm{lbid}, 58$.
} 
as a means of shelter. This private realm stood in contrast to the public realm of political activity. Arendt posits that the building of housing was a means of survival and thus not a part of the public realm. ${ }^{41}$ The issue of housing began to shift from the private realm into the public realm and became more apparent as cities changed into urban metropolises requiring housing for large populations. These issues of dwelling and human necessity became social and effectively required legislative intervention to regulate housing conditions. The immigration policy that led to the present demographic can also be seen as a public issue that should concern all of us, since we are all interconnected economically and socially. The issue of housing the low-income sectors of society should not be ignored because housing is no longer linked to the private realm of human survival - it also exists in the public realm of social deeds. The preservation of Toronto's towers-in-the-park is a social and public response to the needs of the populace.

\subsection{THE TOWER'S AS IMPERECT HOMES TO ONE MI $\amalg$ ION RESIDENTS}

High-rise apartments have been demonized as flawed social experiments. The residential tower form has many detractors, one of which is Christopher Alexander who writes,

High buildings have no genuine advantages, except in speculative gains for banks and land owners. They are not cheaper, they do not help create open space, they destroy the townscape, they destroy social life, they promote

${ }^{41} \mathrm{Ibid}, 61$. 
crime, they make life difficult for children, they are expensive to maintain, they wreck open spaces near them, and they damage light and air and view. But quite apart from all this, which shows they aren't sensible, empirical evidence shows that they can actually damage people's minds and feelings. ${ }^{42}$

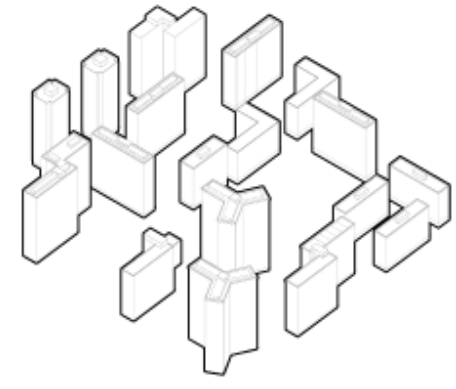

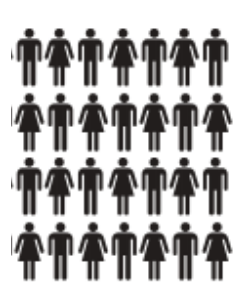

FIG. 16

Conceptual High-rise Housing Diagram

Influx of immigrants and low-income residents into high-rise towers helped them to become homes to $1,000,000$ people
Alexander is well supported by many other critics who contend that high-rise buildings are not good places for younger children because of difficult play arrangements and unease of travel. Many point to inefficient circulation and features. Balconies, for example, are useless because of their shallow depth; they are relegated to outdoor storage areas instead of outdoor retreat spaces, as originally intended. The question of whether the high-rise form was the more suitable choice for housing at the beginning of the 1960s is now moot. The fact is that there are 2,000 towers in the GTA housing more than 1 million people. The rehabilitation of these vertical neighbourhoods is crucial to the well being of their lower-economic demographic.

The high-rise rental towers serve the low-income class and new immigrants and have thus become fixtures of the urban fabric. Many of the residents within these towers-inthe-park rely on public transit and not cars. They consequently cannot afford to live far from transit lines. Toronto has the longest average commute of any Canadian city with about 16 percent of commuters in the GTA driving over 90 minutes each day to and from

${ }^{42}$ John Sewell, Houses and Homes, 49-50. 


\section{0}

60

40

20

0 neighbourhood as good place to live

Agree

FIG. 17

High-rise Tenants' Assessment of Their Neighbourhood work. ${ }^{43}$ These high-rise towers built near transit lines provide greater dwelling capabilities for a larger number of residents in cities. These towers are usually located next to transit lines servicing the poor and working class. The rising costs of owning a car combined with urban sprawl throughout the GTA has made city dwelling more appealing. With more people choosing to remain in the city for the amenities and lifestyle, density becomes a focal point. As such, Toronto has embraced the vertical ascension of housing once again as seen in the city's condominium boom. However, its high-rise rental stock is still a valuable commodity in terms of land use and housing the low-income immigrant demographic.

The buildings, depending on their location, can provide views of the city and the landscape not seen in low-rise residences. They are ideal for the elderly and handicapped where accessibility is a concern. In contrast to concerns over crime in these buildings, residents whom were surveyed by the United Way of Toronto generally reported feeling safe in their building. The crime rate within these building types are on par with the crime rate of the rest of Toronto, which happens to be the lowest of all metropolitan areas in Canada. ${ }^{44}$ It is true, however, that certain buildings and areas are more prone to crime and safety concerns than others. The social capital in these buildings at the present time is greatly diminished by the deficiency of communal space. A careful redesign and

${ }^{43}$ Oliver Moore, The Canadian Commute: By Car Alone, The Globe and Mail, 26 June 2013,

http://www.theglobeandmail.com/news/national/the-canadian-commute-by-car-alone/article12849501/, 15 December 2013. ${ }^{44}$ The Canadian Press, Toronto has the lowest crime rate of Canada's census metropolitan areas, City News Toronto, 25 July 2013, http://www.citynews.ca/2013/07/25/toronto-has-lowest-crime-rate-of-canadas-census-metropolitan-areas/, 21 February 2014. 
reallocation of the spaces within and around these buildings can address their shortcomings, promote better communal living, and enhance social interactions. 


\section{0 (TOWIRS IN TUE) PARK}

FIG. 18

Conceptual Park Diagram

The integration of amenities and social spaces into parks
This chapter discusses the social value of Toronto's park space and the city's plans for renovating parks in an urban area with finite land resource in an attempt to support a growing population. This section emphasizes the importance of park space for the residents of high-rise neighbourhoods. It proposes that the parks beneath the high-rise towers be used for public park space in the city, servicing both the public as well as the private tenants of these buildings.

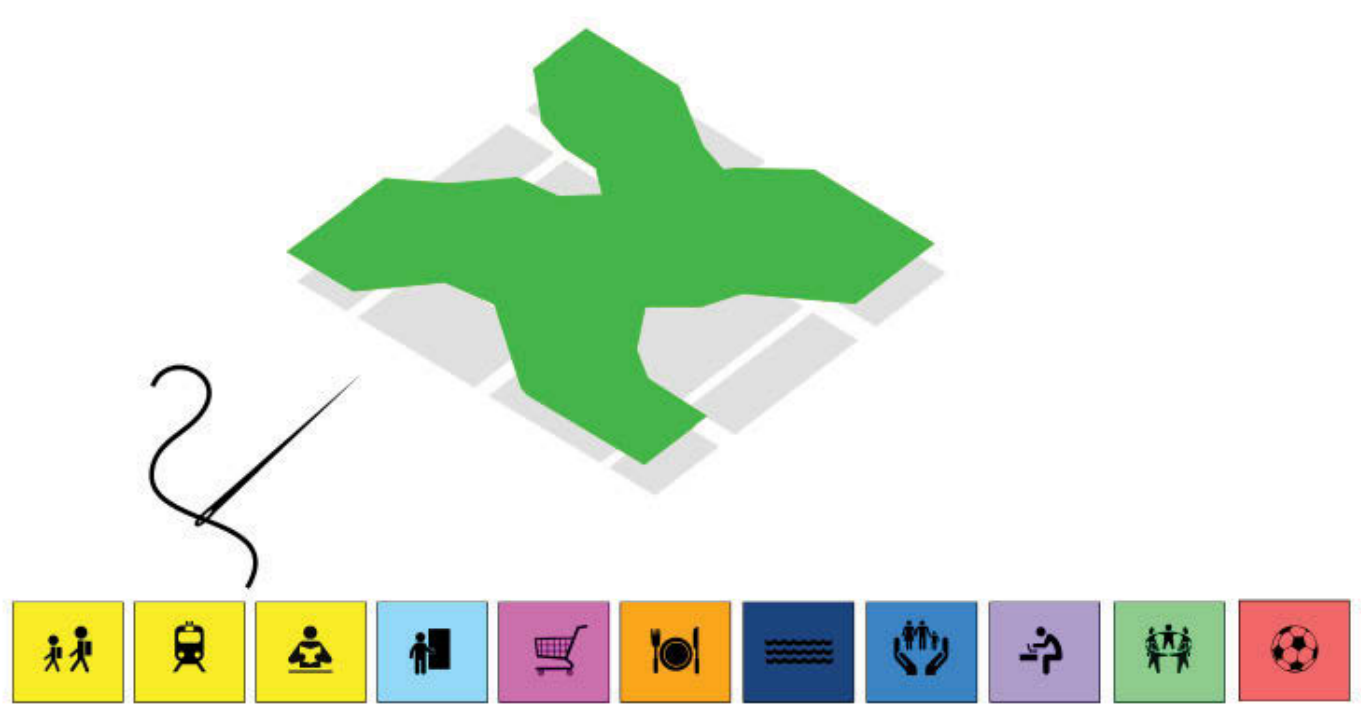




\subsection{PARK AS SOCIAL BINDER FOR TORONTO}

Toronto has more than 1,500 parks which totals 80 kilometres of parklands, ravines, and other garden spaces. There were 8,000,000 visitors to Toronto's parks in 2009. Half of the people in the city visit a park at least once a week and almost 14 percent of the city's residents visit a park every day. ${ }^{45}$ These parks play a crucial role as a social binder for the city's diverse population. With the city's projection of its population adding half a million people by $2031,{ }^{46}$ parks will fundamentally become a place of social refuge. Overall, 18.1 percent of the city's surface is covered with natural spaces and parks compared to 27.4 percent of the surface which are paved roads and highways. ${ }^{47}$ Toronto is presently going through a vertical housing boom that encourages high-rise and high density living in condominiums and apartments. This new density will put greater pressure on parks as residents seek recreational spaces. Parks act as public spaces where people can engage with their community and prevent isolation. Urban park expert Peter Harnick writes, "Parks, ultimately, are an interplay - a conversation if you will - about the relationship between people and nature." ${ }^{48}$ Harnick implies that parks contain a human element that is often overshadowed by the park's aspect of nature. Parks in urban areas must first and foremost consider people. Parks can create a connection between the environment and peoples, resulting in a holistic sense of community and place.

\footnotetext{
${ }_{45}^{45}$ David Harvey, Fertile Ground for New Thinking: Improving Toronto's Parks (Metcalf Foundation, 2010), 4.

${ }^{46}$ Ontario Population Projections Update, Ontario Ministry of Finance, Spring 2013,

http://www.fin.gov.on.ca/en/economy/demographics/projections/, 21 February 2014.

Community Foundations of Canada, 2009 Vital Signs Report, and Spacing Magazine, Winter 2009.

${ }^{48}$ Peter Harnick, Urban Green: Innovative Parks and Resurgent Cities (Island Press, 2010), 8 as quoted in David Harvey, Fertile Ground for New Thinking: Improving Toronto's Parks (Metcalf Foundation, 2010), 9.
} 
Creating new parks in Toronto proves to be a challenge because the city's land is limited and is largely allocated to other uses. Toronto is now looking to large cities such as New York, Chicago, and Los Angeles that have turned portions of their streets and unused city lands into new park space in an attempt to find alternatives to traditional parklands. New efforts by the city to accumulate more park space have also at times aligned with private investment. Oftentimes, developers strike deals with the city whereby they are allowed to build to taller heights in exchange for the construction of new park space. The city should look at acquiring private land at the foot of its own high-rise rental buildings that have significant potential park space that is left unused by its residents due to its poor design. Planning regulations at the time these buildings were constructed allowed for up to 90 percent of a lot to be dedicated to open space creating breathing room and unobstructed light into the units. This remains the status quo for the majority of the buildings today. There are more than 1,000 high rise towers in Toronto, each with park space at the bottom for the city to accumulate. This investment would benefit both the city by acquiring potential public park space, as well as the private building owners who can reinvest the purchase price in building repairs and relinquish the maintenance of the grounds to the city. 


\subsection{PARKS AS COMMUNAL AND RECREATIONAL SPACE FOR TOWBR RESIDENTS}

high-rise rental apartments, parks become crucial community spaces to combat the high density and lack of amenities of the towers-in-the-park. The city's park space can become potential living rooms and backyards for the tower's residents. Furthermore, studies have shown that although immigrants usually arrive in Toronto in good health, a combination of stress, inadequate diet, and inactivity translates into deteriorating health. Toronto Public Health found that isolation and lack of integration contribute to a 50 percent higher rate of inactivity for immigrants. ${ }^{49}$ This is especially true for senior immigrants, especially women, do not travel far from their homes and immediate neighbourhoods. Refurbishing the existing park beneath the towers with programmed spaces and activities can provide an alternative to the lack of amenity and recreational spaces inside the buildings.

The communal park space can also prove beneficial for the residents' health. There is a growing emphasis on raising children in physically, emotionally, and mentally healthy manners. Parks foster healthier communities. People who live in neighbourhoods containing parks reported to have lower rates of obesity and diabetes. The Toronto Community Foundation's 2009 Vital Signs report found that 7 out of 10 Toronto neighbourhoods with the highest rate of diabetes lacked access to parks, schoolyards, and recreation centres. All 10 of the neighbourhoods were low-income neighbourhoods. A 2009 study published in the Archives of Internal Medicine discovered that people who

${ }^{49}$ Sheela Basrur, Physical Activity and Public Health: A Call to Action, Medical Officer of Health (City of Toronto Staff Report, 2013), 14. 
live in neighbourhoods that support physical activity were 38 percent less likely to get diabetes. ${ }^{50}$ A 2007 study by the New York University Furman Centre for Real Estate and Urban Policy also found that community gardens in New York's poorest neighbourhoods had lifted property values by more than 9 percent over five years. ${ }^{51}$ A re-design of the park space beneath residential towers can help provide outdoor recreational spaces and connections between neighbouring buildings. They can become communal focal points promoting interactions between neighbours and also connect the buildings back to the city.

\subsection{PARK AS CONNECTION BETWMN TOWERS AND STRIITS}

The towers-in-the-park as proposed by Le Corbusier pulled away from the bustling streets aiming to avoid the dust, smells, and noise of the city. ${ }^{52}$ The pull of the high-rise tower to the centre of a city block was intended to allow gardens to grow and to provide space for play fields. When the form was realized in Toronto during the 1960s, however, the parks were distilled to barren lawns with little life because of the lack of investment by the buildings' owners. The separation from the street isolated the buildings from the rest of the city. Jane Jacobs reasons that the street is where all cities begin. She goes on to say, "Streets and their sidewalks - the main public places of the city - are its most vital organs." The separation of these towers from the streets created an isolation that excluded the residents from city life. The connection of the towers to the streets can be

\footnotetext{
${ }^{50}$ David Harvey, 13.

${ }^{51}$ Ibid

${ }^{52}$ Le Corbusier translated by Frederick Etchells, Towards a New Architecture (New York: Dover Publications Inc. 1986), 56.
} 
repaired with a careful reimaging of the unused park space below a building. The park space can become a connection or extension of the public realm and life-force of the city. Emily Waugh who is the editor of landscape designer, Martha Schwartz's book, Recycling Spaces, writes, "Parks and open spaces do not only adapt to forces of change, but also have the power to guide, shape, and curate the evolution of cities as the most effective catalysts for urban transformation." She goes on to say:

Within these constantly evolving urban conditions, the city's public realm landscape - streets, parks, and open spaces - carry an intense responsibility as the shared resources of the city and the physical connections that bind it together. ${ }^{53}$

Parks can be instrumental players in the union of these high-rise towers by connecting their tenants to the rest of the city, promoting a more cohesive community.

\footnotetext{
${ }^{53}$ Emily Waugh, Recycling Spaces, Curating Urban Evolution: The Landscape Design of Martha Schwartz Partners (London, Thames and
} Hudson Ltd. 2011), 11 


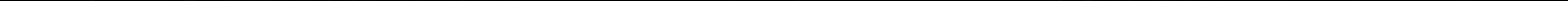




\section{$\triangle \triangle O S T$. JAMES TOWN, $\square \square \sqrt{\square(C)}$}
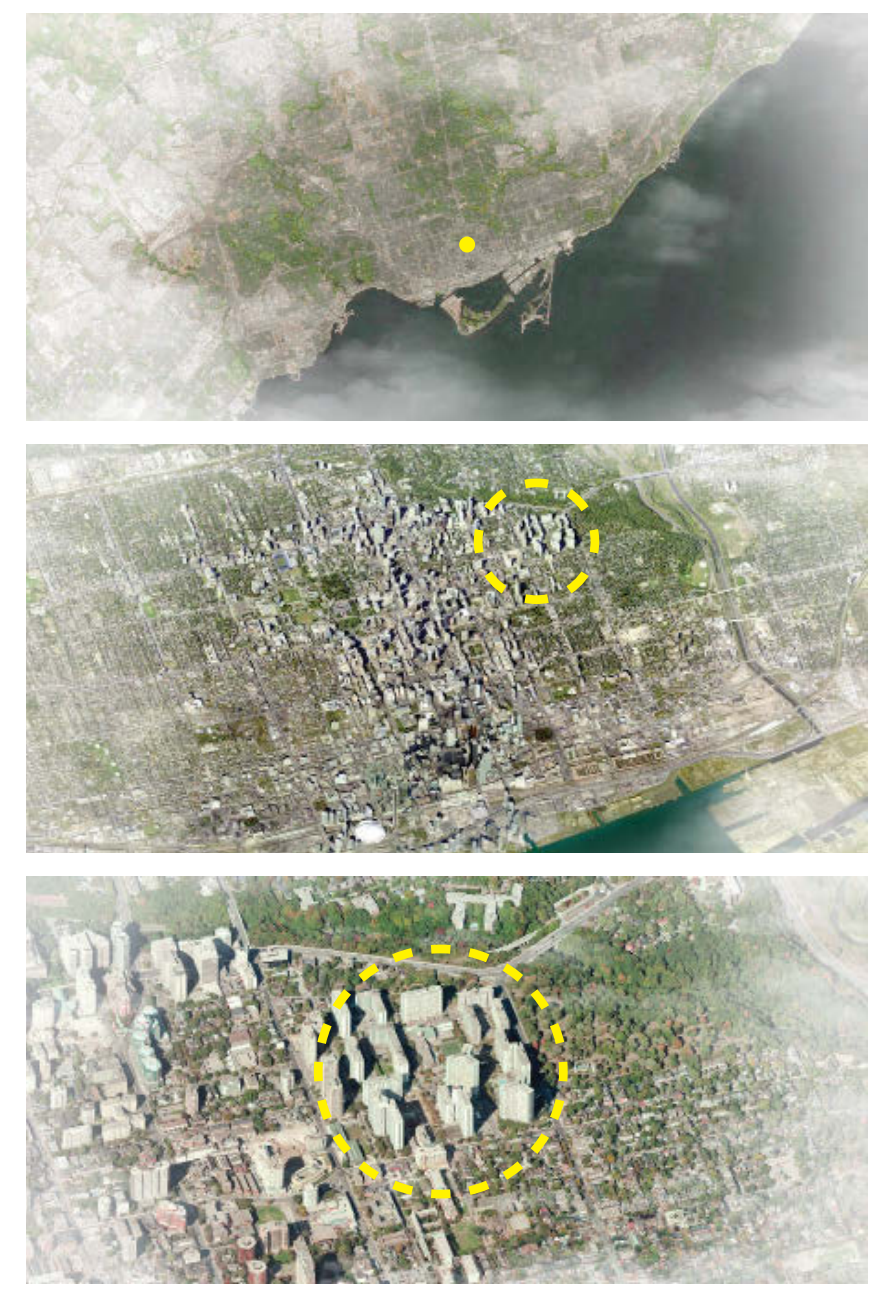

FIG. 20

Existing St. James Town Site Aerials

A. Greater Toronto Area

B. Toronto city center
This chapter discusses the neighbourhood of St. James Town as the site in Toronto for a proposed design project to rehabilitate its towers-in-the-park and surrounding lands. First, this section recounts the history of the site following the narrative of housing in Toronto (Section 2.1). Second, there will be an examination of the neighbourhood's needs for renewal, the common thread of degradation due to aging systems, increasing building densities, and loss of communal spaces with the other high-rise housing clusters in Toronto (Section 2.3-2.5).

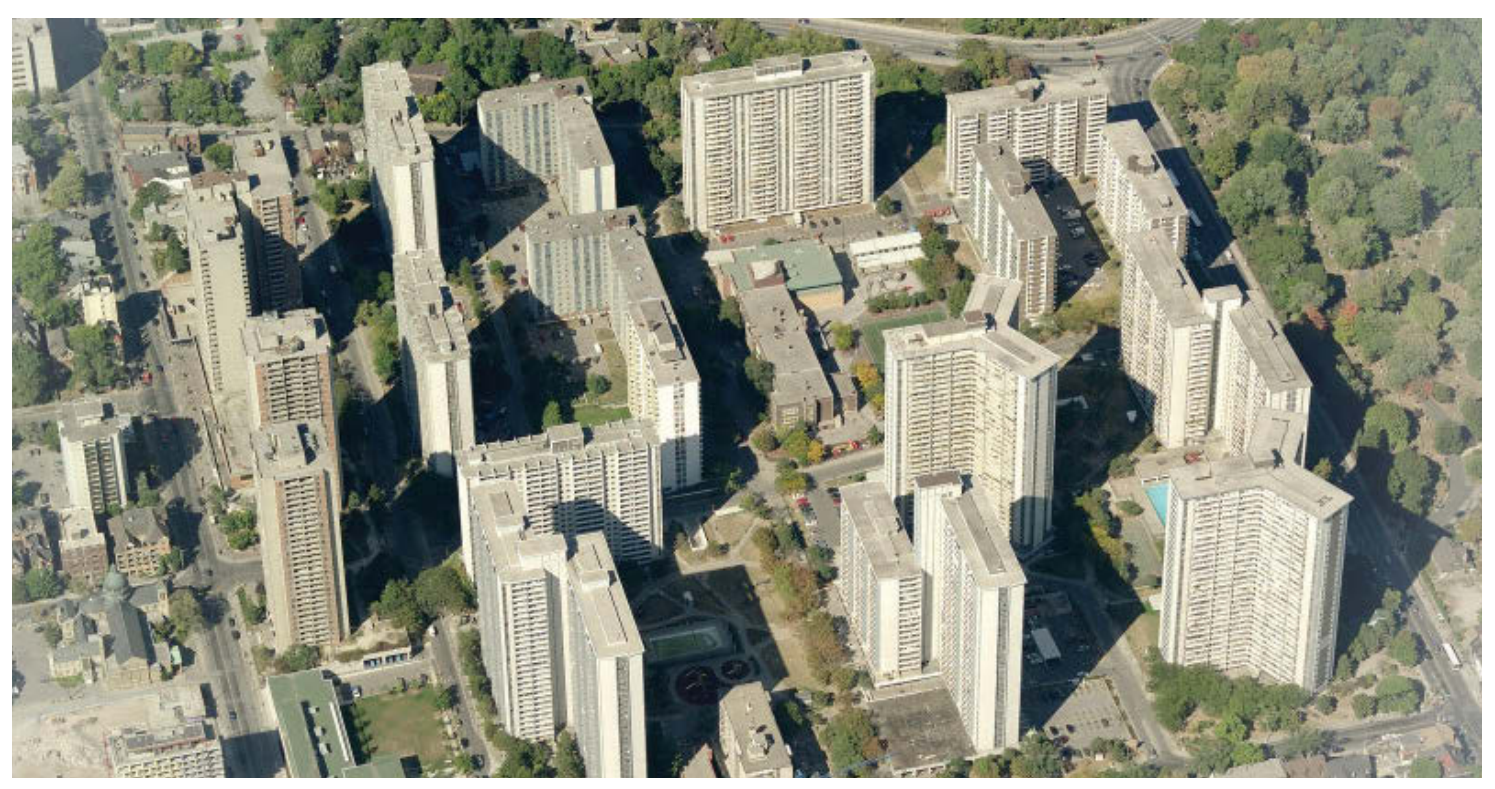

A. St. James Town neighbourhood and surrounding context B. St. James Town neighbourhood close-up 


\subsection{A HISTORY OF ST. JAMES TOWN : THE DEMOLITON OF HOUSES}

St. James Town is located just northeast of Toronto's downtown district of commerce and politics. It is bounded by Wellesley Street to the south, Sherbourne Street to the west, Howard Street to the north, and Parliament Street to the east. The St. James Town area originally consisted of two and three storey houses built in the 1870s for the upper middle class before the area was rezoned 1953 for high-rise residential construction. ${ }^{54}$ St. James Town became the first private sector built high-rise housing project in Canada after clearing the houses in the area at the beginning of the 1960s. In the case of St. James Town, agents operating for a development consortium called the Parliament Street Syndicate began procuring homes in the area at the start of the1950s. ${ }^{55}$ It was also during this time that the suburban surroundings were rapidly expanding and drawing the middle class away from the city's centre. Toronto City Council looked to Europe and specifically Le Corbusier's "City of Towers" ${ }^{56}$ as inspiration for a new housing form in the city. City planners saw this new wave of high-rise apartments as the future of housing and a way to retain the middle class within the city and prepared for it as such by rezoning the area to allow for a density of 3.5 square feet of floor space for every square foot of land. Since areas of houses around the downtown core were generally zoned at less than one times coverage, this new designation was very enticing to the private sector with its potential to maximize land development. ${ }^{57}$

${ }^{54}$ John Sewell, The Shape of the City, 163

55 Ibid, 170.

FIG. 21

${ }^{56}$ Le Corbusier translated by Frederick Etchells, Towards a New Architecture (New York: Dover Publications Inc. 1986), 56-57.

\section{Newspaper Clipping}

${ }^{57}$ John Sewell, 163

Newspaper article depicting block busting tactics

(April 13, 1971) 

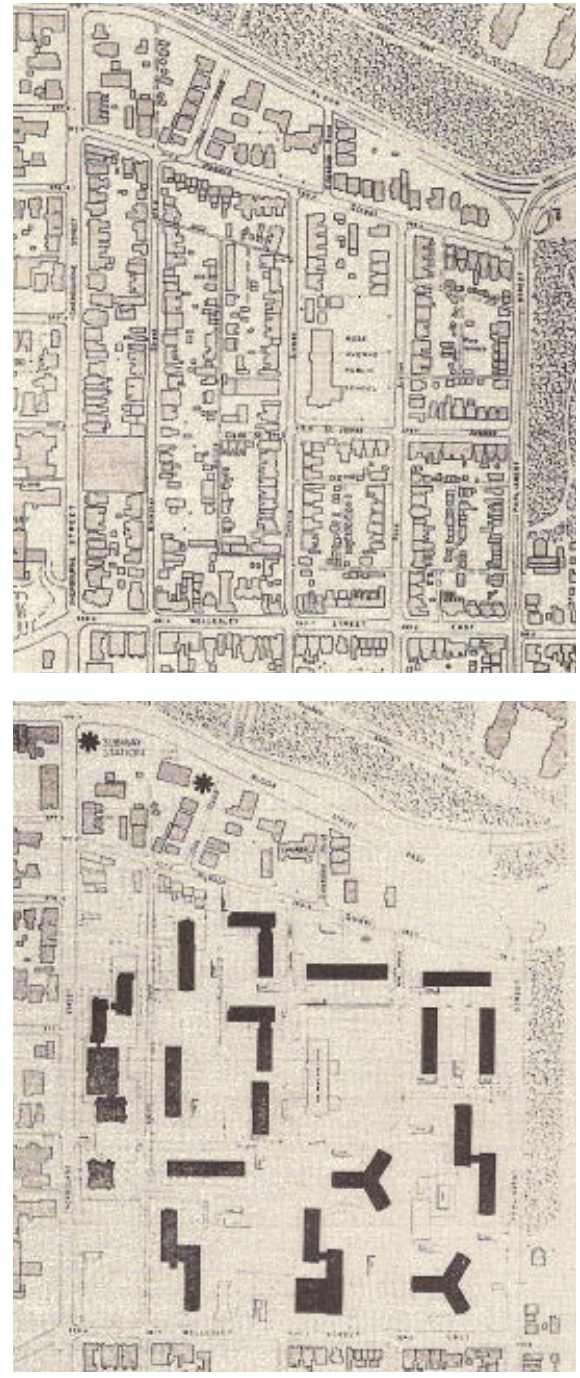

FIG. 22

St. James Town Historic Site Plans

A. St. James Town neighbourhood plan before 1960

B. St. James Town neighbourhood plan after developement in 1970
By the middle of 1956 more than half of the 435 homes had been purchased or were under option, sealing the fate of the community. With such a high proportion of homes controlled by developers who intended to demolish them, incentives for city maintenance quickly disappeared and properties fell into disrepair. The city stopped funnelling services to the area once the developers started to accumulate properties thus expediting the selloff of the remaining homes. This tactic known as "block busting" was used by developers to run down properties they controlled, forcing holdout owners to consider selling quickly, making redevelopment inevitable..$^{58}$

\subsection{A HISTORY OF ST. JAMES TOWN : THE RISE OF THE TOWBRS IN THE PARKS}

The block busting tactics of developers and the rezoning of the city allowed St. James Town to transform from a collection of family homes to a cluster of high-rise towers set in green grass. Canadian architect, A.S. Matthers spoke of Le Corbusier's towers in the park in a 1940 speech saying, "The technique of the tall building can be used to release the ground with its grass and trees, for the use of the city dweller. ${ }^{.59}$ Corbusier suggested that pulling buildings away from the streets and placing them at the centre of the block was the best way to bring light and air to the units. The modernist image of the tower in the park was supposed to attract the middle class back to the city or at least to stave off

\footnotetext{
${ }_{59}^{58}$ John Sewell, The Shape of City, 166.
}

${ }^{59}$ Ibid, 34. 


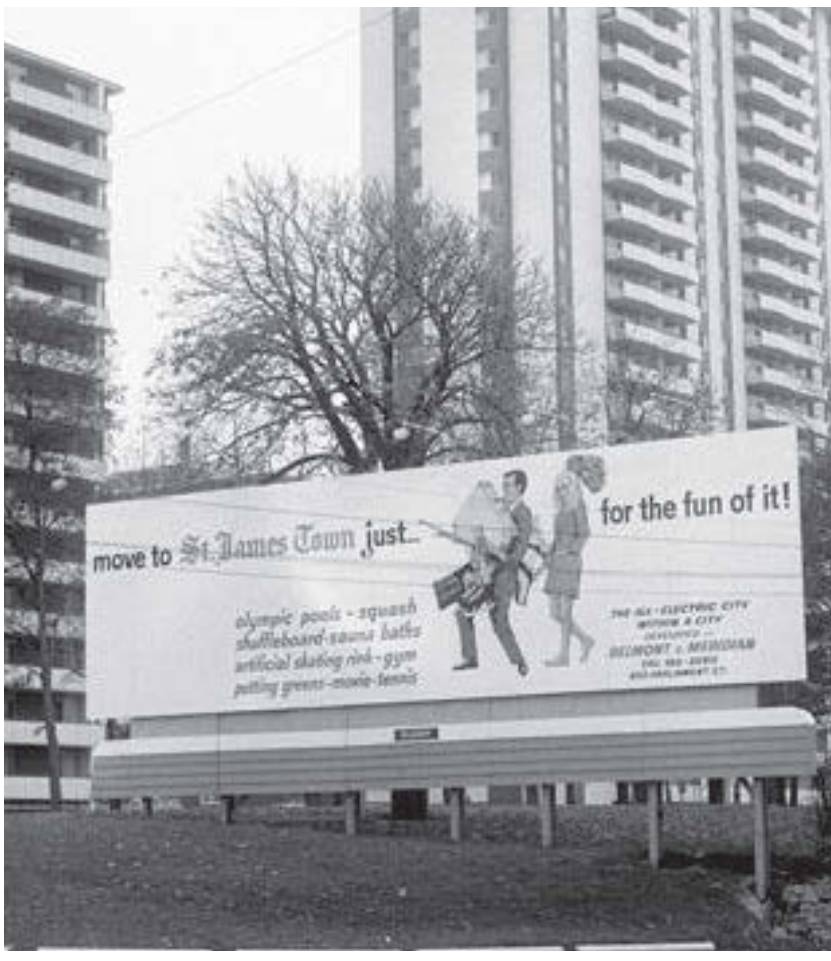

FIG. 23

St. James Town Billboard

Advertising for St. James Town to young professionals, 1970. further exodus. The hope was that the middle class would re-discover a city comprised of fresh residential towers, flooded with light and air that contained modern appliances and central heating. The prospective inhabitants would discover acres of family-friendly green space enveloping the feet of these towers, rather than noisy streets crowded by strangers.

St. James Town's new high-rise towers were directed specifically towards single young professionals at the end of the 1960s as evidenced by the large proportion of bachelor and one-bedroom apartments. The community's intended demographic was different from the family focused demographic that Le Corbusier envisioned. Some of the buildings went as far as having "adults only" regulations prohibiting children from entering the area. ${ }^{60}$ This was the antithesis of what Le Corbusier's towers-in-the-park were supposed to accomplish. Green parks at the base of the new towers were intended to serve as areas of refuge and social interactions. Instead of having children run freely on the park grass below and their parents looking on from their units, the ground plane became desolate and unused. While initially the towers did attract young professionals, as noted earlier, they eventually migrated to the suburbs. This evacuation left a vacancy within this housing form which was then filled by immigrants. The community primarily houses lowto-moderate income families and has been a major settlement area for newcomers to Canada. This has created an ideal situation to revisit the planning of the landscape park on the ground plane as well as the common spaces inside the buildings to provide the

\footnotetext{
${ }^{60}$ Cabbagetown Preservation Association Newsletter, Breezes of Change Lift St. James Town (Autumn 2012), 2.
} 
families of the community areas to escape from their tower units and for public congregation.

\subsection{ST. JAMES TOWN AS IT EXISTS TODAY}

St. James Town as it exists today is consists of approximately 17,000 residents living in 18 high-rise rental towers on a 32 acre site, making it the most densely populated area in Canada. That number of residents is thought to be close to 25,000 due to overcrowding and having families cohabitate in single units. ${ }^{61}$ The resident population is made up of a very large number of recent immigrants: 41.1 percent of the population arrived in Canada within the previous five years, which is almost double Toronto's average of 23.1 percent.

The population is extremely diverse. More than 85 percent of the students in the local junior public school speak English as a second language and collectively represent over 50 language groups. The neighbourhood also exhibits a high degree of transience. Approximately 18 percent of the residents have moved in the previous year, compared to a Toronto average of 14.6 percent. St James Town moreover displays a younger age demographic than found across the city of Toronto as a whole. Just over 15 percent of the population is age nine years or younger compared to the city rate of 11.8 percent. Residents aged twenty to thirty make up 16.7 percent of the population as opposed to the 14.6 percent of Toronto, and 7.3 percent of the population who are seniors versus 9.6

\footnotetext{
${ }^{61}$ Kevin Perkins and Tom Zizys, St. James Town Neighbourhood Toronto: Overview and Prospects for Community-Based Poverty
} Alleviation Initiatives (Toronto: World Vision Canada, 2005), 5. 
percent of the rest of the city. Additionally, 24.1 percent of all families in St. James Town are headed by single mothers as opposed to 16.8 percent for the rest of Toronto.

St. James Town is a very much a low-income neighbourhood. There is almost twice the poverty rate in the community as there is in the rest of the city. The participation rates in the labour force and the employment rates for youth are especially low. Among those who are employed, there is a significant concentration of jobs in sales and service, manufacturing, and general labour. Despite significantly higher incidences of poverty and greater participation in lower-skilled jobs, the educational background of St. James Town is actually slightly higher than that of the rest of Toronto. ${ }^{62}$ What these numbers indicate is that the residents of St. James Town are young and educated, but they have a difficult time obtaining jobs due to the lack opportunities in their field but likely as well due to racism and barriers established by provincial organizations to limit foreign professionals.

When these young and educated residents do find employment, they ultimately move out of the area.

\subsection{ST. JAMES TOWNS DEFICIENCIES}

The neighbourhood sees a large turnover of its residents which stems from the poor living conditions of the units, the lack of amenities and services in the area due to the city's and landlords' neglect. The parks that were meant to service the community when the towers were first built are barren and deserted the majority of the time. This vacancy was a result

${ }^{62}$ Ibid, 7-9. 

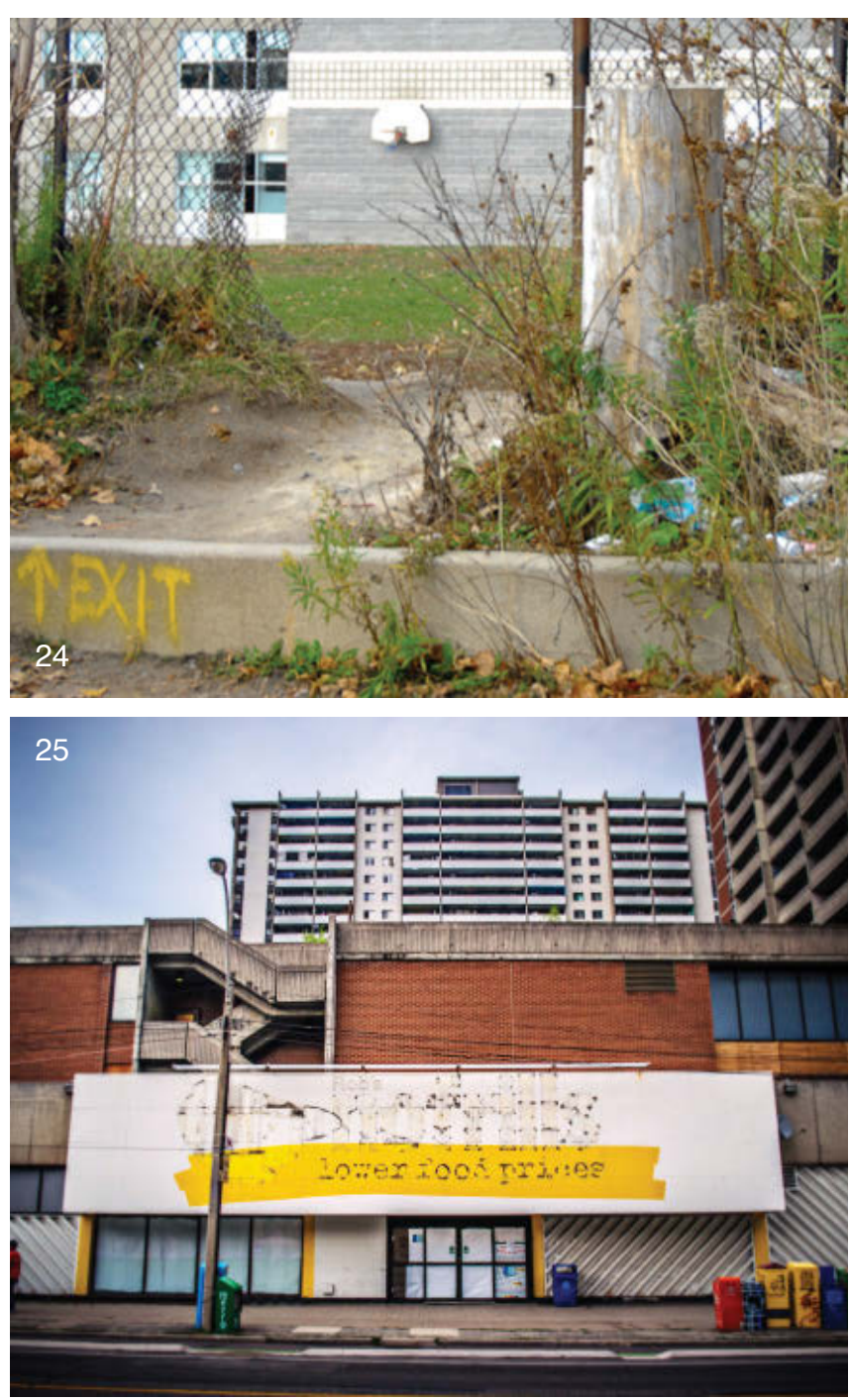

FIG. 24

Fences dividing adjacent buildings

FIG. 25

Grocery store abandoned on Sherbourne Street of discrepancies among private developers. The neighbourhood was not conceived by a single entity working towards a unified goal, but rather by a multitude of private developers, including Central Mortgage and Housing Corporation, Shabse Frankel, Belmont Construction, Meridian Development, and the Rose Park Group. ${ }^{63}$ With various developers building St. James Town, there lacked continuity and a cohesive plan for the public realm on the ground plane. Without a master plan from the city for the neighbourhood, the private owners of the towers were not obliged to provide public amenities in the parks nor any access to surrounding towers. At the time, more emphasis and value was placed on surface parking than outdoor park facilities. Fences and boundaries were quickly raised and that further increased the separation between neighbours. Concrete paved parking lots litter the site diminishing connection between adjacent buildings, and are now generally dumpster and garbage sites. Public access to transportation and walking paths were poorly planned or non-existent. ${ }^{64}$ As a result, the ground plane became largely uninhabited. A new landscape is necessary to thread together the neighbouring residential communities to the east and west of the site to the residents within St. James Town.

There is also a shortage of retail and businesses in the area to support to the large number of residents. Commercial spaces were not a part of the original plan for the community. Residents often find themselves having to travel further away from the community to get supplies or groceries. The businesses that are in the area now are

${ }_{63}$ John Sewell, The Shape of the City, 166.

${ }^{64}$ Jane Farrow, Walkability in Toronto's Apartment Neighbourhoods: Preliminary Report on St. James Town Walkability Workshop (Toronto, 2009) 21-24. 
scattered throughout the neighbourhood located on the ground floor of the towers. The retail spaces do not engage the street and often goes unnoticed. A new concentrated retail area is needed to help serve the residents of the community.

\subsection{R日ABI TTATION TACTICS FOR ST. JAMES TOWN}

The neighbourhood's landscape and more specifically the land beneath the towers are also uncared for and become wasted space that could be used for community functions. Providing the city of Toronto with new landscaped parks that function as a beacon and meeting place for the community would also remedy some of the residents' grievances of the building's lost communal and social spaces. A new series of public parks will help to reinvigorate the area and help to provide amenities for families and hopefully change the misconceptions of the community, nurturing new opportunities for retail and business. Positives of park space (outlined in Section 3.2) for St. James Town's tenants can include recreational spaces promoting better healthy living, social interaction, community cohesion, decreased feelings of isolation and crowdedness, and increase in the buildings' equity.

The buildings and their subsequent systems are in desperate need of repair and replacement. The repair of one issue often entails dealing with another; thus, it would be recommended that the repairs to a building be done holistically. Rehabilitating the buildings means a complete stripping of its crumbling facade and balconies, replacing it with a more energy efficient envelope. The existing concrete structure would be 
preserved and incorporated into the new units. The units would have to be enlarged, amalgamating adjacent apartments to create larger units for multiple families in order to address the concerns of crowdedness. Also, towers will have to be expanded to accommodate larger and greater common spaces for recreation and community exchange. More housing units will be added to existing buildings, as well as units to the site in order to maximize the site's density while still retaining the community atmosphere without the sense of crowdedness.

\subsection{RECONNECTING ST. JAMES TOWN TO THE CITYS STRIIS WITH PARKS}

The neighbourhood today is considered as a blight in the city and an example of vertical poverty. The most densely populated neighbourhood in Canada does not have an opportunity to display the diverse cultures and people that comprise this unique community. Its present state undercuts the aspirations and potential of the immigrants who are otherwise eager to contribute to Canadian society; this de facto launching pad for new immigrants is poorly planned and largely ignored by the city. Already surrounded by public transit routes and major roads, the area is gifted with an opportunity to reconnect with the rest of the city of Toronto by providing the larger city area with new public parks that will draw fresh life into what is currently a desolate ground plane. The buildings were pulled from the streets into the centre of the city block and distanced from the life of the city (as discussed in Section 3.3). These parks could also grant the city's wish of obtaining more park land to service the growing population of Toronto. The parks 
would be managed by the city---rather than the tower owners---and as such would serve the residents as well as the public. The landscape design for the area beneath the towers aims to reconnect these towers back the life of the street, engage the public, provide community spaces for the residents, and ultimately serve as a new social hub for the city. 


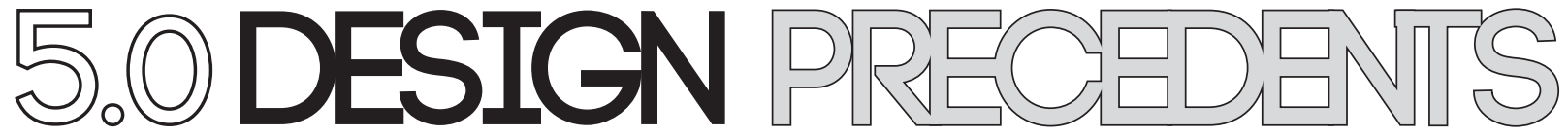

This chapter discusses two contemporary architecture projects that attempt to rectify problems of density and social integration. The first project analyzed is Steven Holl

Architects' tower project in China titled "Linked Hybrid." Secondly, there is an examination of Bjarke Ingels Group's "Superkilen” urban park in Denmark. Linked Hybrid represents a marriage of density and amenities resulting in a project that socially binds the residents to the community. Superkilen, on the other hand, represents a new perspective on an urban park that unites a community of various backgrounds. The undertones of providing communal spaces for people in order to foster social capital is apparent in both projects and thus provides a lens to observe architectural elements that might resolve some of the difficulties of St. James Town. 


\subsection{LNKED HYBRID - STEVEN HOL ARCHITECTS}

Linked Hybrid is a 220,000 square meter housing project located adjacent to the old city wall of Beijing in China. The project was completed in 2009 and encompasses eight housing towers joined by a network of underground parking and a series of enclosed sky bridges. The complex contains within it 750 apartments, 60 hotel rooms, public green space, retail shops, a cinema, a kindergarten, a Montessori, galleries, and an underground parking garage. The project is described as an "open city within a city" with its mixed-used programming. ${ }^{65}$ Linked Hybrid provides an alternative to the privatized urban developments in China. Its porous urban edge allows the pubic to penetrate the complex from the perimeter street. The complex facilitates social interaction and encourages encounters within the multifaceted public spaces that range from commercial, residential, educational, to recreational. The project also makes use of the natural landscape and conditions of the site by using geo-thermal wells from 100 to 655 meters deep to provide the complex with cooling in the summer and heating in the winter. $^{66}$ Linked Hybrid is a pedestrian-oriented combination of public and private spaces that encourages the use of shared resources to foster interactive relations.

The porosity of the ground level includes open passages to allow both residents and visitors to walk through. The ground level becomes the public forum on which social interaction and human encounters occur. Shops situated around a central reflecting pond are used to activate the urban space on the ground plane with retail and commerce

FIG. 26

Perspective of park from sky bridge, 2012

FIG. 27

Perspective of pond from ground plane, 2012
${ }^{65}$ Albert Ferre, Total Housing: Alternatives to Urban Sprawl (Barcelona, Actor, 2010),332.

${ }^{66}$ Steven Holl Architects, Linked Hybid, http://www.stevenholl.com/project-detail.php?id=58, 16 October, 2013. 
for the community. The activated ground plane and all its programming are connected with vegetated spaces and landscape surrounding the complex. The intermediate level of the lower buildings contains public roof gardens that offer contrast from the more lively ground plane. Additional private roof gardens are located at the penthouses at the top of the eight residential towers. ${ }^{67}$ Linked Hybrid's contribution to the public realm and the community is emphasized by the connections, access, and social activity of its ground plane.

Linked Hybrid provides additional amenity space by knitting the towers together with sky bridges. The sky bridges are a series of enclosed walkways between the towers and connect the eight residential towers and hotel on the twelfth to eighteenth floors. The series of sky bridges form a connecting loop of programs shared within the towers that includes a swimming pool, fitness centre, cafe, gallery, auditorium, and salon. Programmatically, the loop aspires to be what Holl calls a social condenser, generating random relationships and encouraging encounters like that of the public street. ${ }^{68}$ The project seems to achieve what Jane Jacobs advocated when she said:

In China everything revolves around the car, which means the pedestrian environment is missing, including the pedestrian-friendly architecture of interlinked buildings. The potential to have the full range of ecocity design

\footnotetext{
${ }^{67}$ Albert Ferre, Total Housing: Alternatives to Urban Sprawl (Barcelona, Actor, 2010),328.
} ${ }^{68}$ Ibid, 330. 
features, such as bridges between buildings, rooftop terracing, and multi-story solar greenhouses, has yet to be explored. ${ }^{69}$

These sky bridges and underground parking sandwich the ground plane creating two connective levels of programming. Linked Hybrid complex counters the current urban developments in China by creating a new urban space that encourages social interaction within its public spaces.

Linked Hybrid's supply of communal spaces provides a social framework on which social capital can grow. These spaces, as reported by the United Way in their tenant survey (Section 2.5), plays a vital role in the health of vertical buildings especially those that are higher than the intended density. They provide a breakout space where people are not quarantined in their units but are able to participate in group activities and events. Holl's project not only provides a public sphere on the ground floor but also a connection of amenities on top linking the towers together. These sky bridges are not like "streets in the air" of other failed housing experiments. ${ }^{70}$ They are used to connect programming and provide access to shared amenities. For example, locker rooms, the sports club, and the health spa are all connected via a sky bridge. The density of the site with its shared programming will ensure that these sky bridges are used and not abandoned like streets-

\footnotetext{
${ }^{69}$ Richard Register, What We See: Advancing the Observations of Jane Jacobs (Oakland, New Village Press, 2010),221.

${ }^{70}$ Streets in the air were first introduced by Alison and Peter Smithson in their Golden Lane Project during a competition to reconstruct post war ruins in London. These streets-in-the-air were open corridors on alternative floors that connected residents to their units. They were planned as a substitute for the streets on the ground. Social housing projects in the United States adopted this idea but they ultimately failed due to a lack of activity and maintenance. They were used merely as a corridor to get into and out of apartments. John Dutton, Plan of the Month: Smithson's Golden Lane Project (1952) 26 May 2013, http://www.grids-blog.com/wordpress/plan-of-themonth-smithsons-golden-lane-project-1952/, 25 March, 2014.
} 

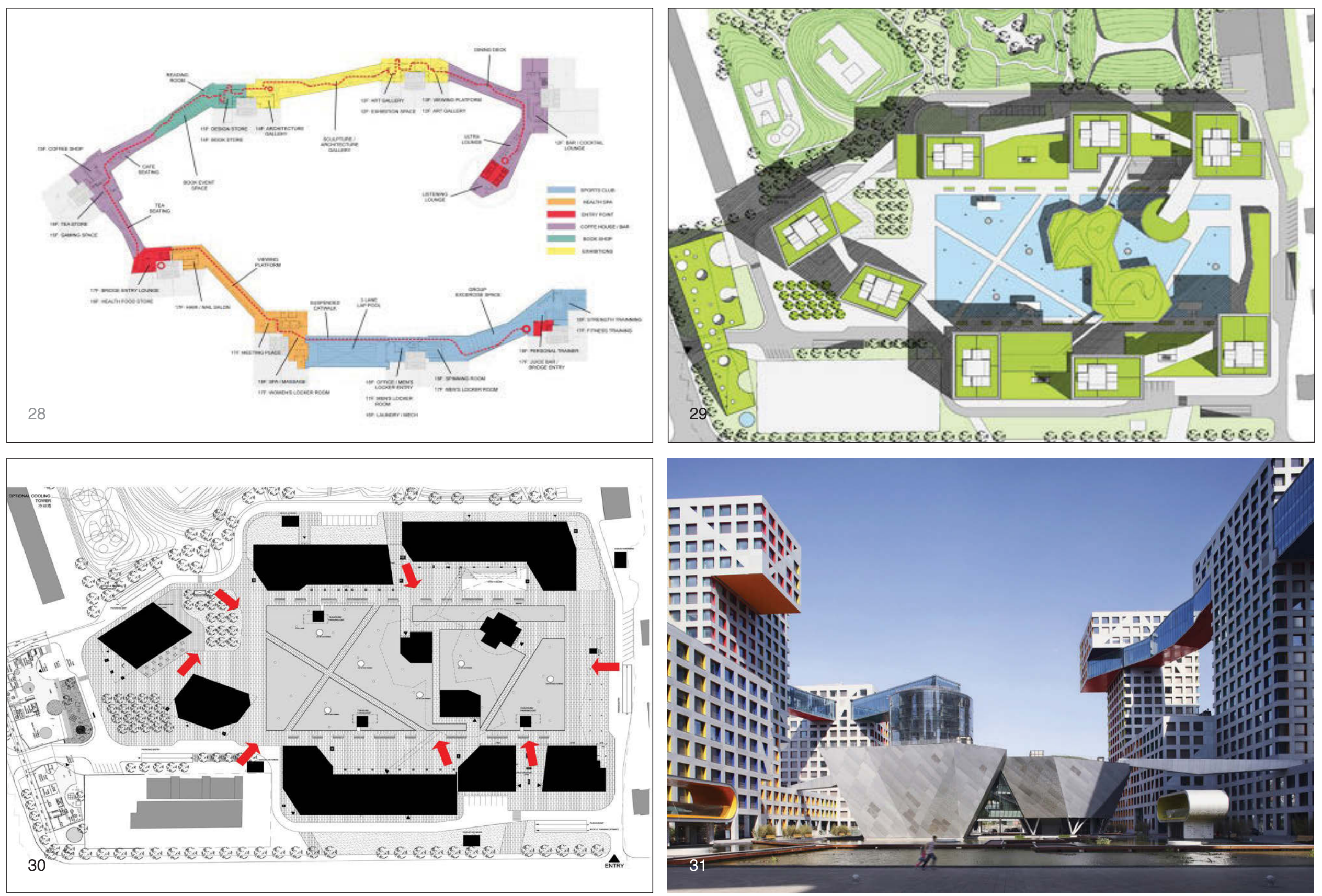

FIG. 28 - Plan of linked programs with sky bridges

FIG. 29 * Roof plan showing green roofs and landscaping
FIG. 30 - Landscape plan showing entrances from the street

FIG. 31 - Perspective of theatres on ground plane, 2013 
in-the-air. However, having these amenities up in the air away from the street segregates it from the rest of the city. The project arguably endeavours to connect to the community but having the sky bridges away from the ground plane partly isolates itself from the community. The idea of connectivity of facilities and communal living tactics are adopted in the proposed design component of this thesis.

\subsection{SUPERKIDN - BJARKE INGES GROUP}

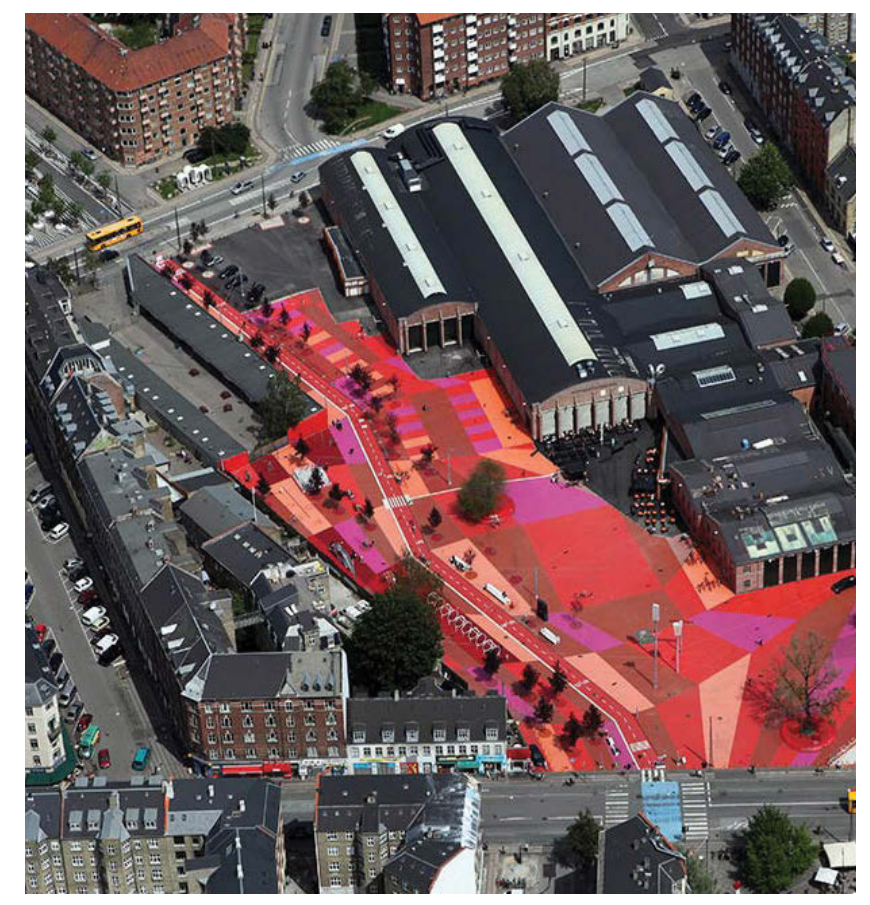

FIG. 32

Site aerial of red segment of park
Superkilen is a kilometre long urban space that ties together the most ethnically diverse and socially challenged neighbourhood in Copenhagen, Denmark. The neighbourhood that the project passes through contains sixty different nationalities on a small footprint, becoming a vehicle for integration. Conceptually the park is a collection of found objects coming from the nationalities represented in the neighbourhood. Items range from exercise gear from muscle beach in Los Angeles to sewage drains from Israel, to palm trees from China and neon signs from Qatar and Russia. The park introduces bits and pieces that represent the people in the neighbourhood which celebrates ethnic diversity fostering a sense of community. The design team reached out to the community for input and ideas and consolidated them all in an urban park for the "people by the people." ${ }^{11}$ Bjarke Ingles says,

The park becomes an urban safari into the diversity of the manmade forms of urban furniture from around the globe: A muscle beach combing elements from

\footnotetext{
${ }^{71}$ Bjarke Ingels Group, Superkilen, http://www.big.dk/\#projects-suk, 20 October 2013.
} 
Venice Beach with Thai Boxing and Chinese pole dancing and an outrageous Estonian swing.

Superkilen is divided into three zones, each with a corresponding colour: green, black, and red. These different zones provide the surfaces for the found objects from all over the world. The park is predominately hard paved, while the green zone is an area of grassy hills and a sports field. The green area has soft surfaces and is meant to appeal to families and young children. The black section is the centre of the kilometre long park and acts as the meeting place of the community. The area contains a fountain, tables, and benches, which conceptually creates an urban living room. The furniture's existence in the park is emphasized with fluid white lines painted into the ground surface. The red section is paved in rubber and programmed for sports and recreational activities for both children and adults. Vegetation is scattered through the paved black and red areas as islands of diverse plant species and trees matching the origins of the diverse objects. ${ }^{72}$ The project as a whole celebrates the diversity of the community and connects different programs and activities.

The park connects three city blocks with streets and bicycle lanes interlacing residents with the park and the park with the city. The different objects-in-the-park is a testament to the ethnic diversity of the community and helps create moments of interaction between neighbours. The park links programs, age groups, and national backgrounds to create a

${ }^{72}$ Superkilen/Tooted 1 + BIG + Super flex, Arch daily, 25 October 2012, http://www.archdaily.com/286223/superkilen-topotek-1-bigarchitects-superflex/,30 March 2014 

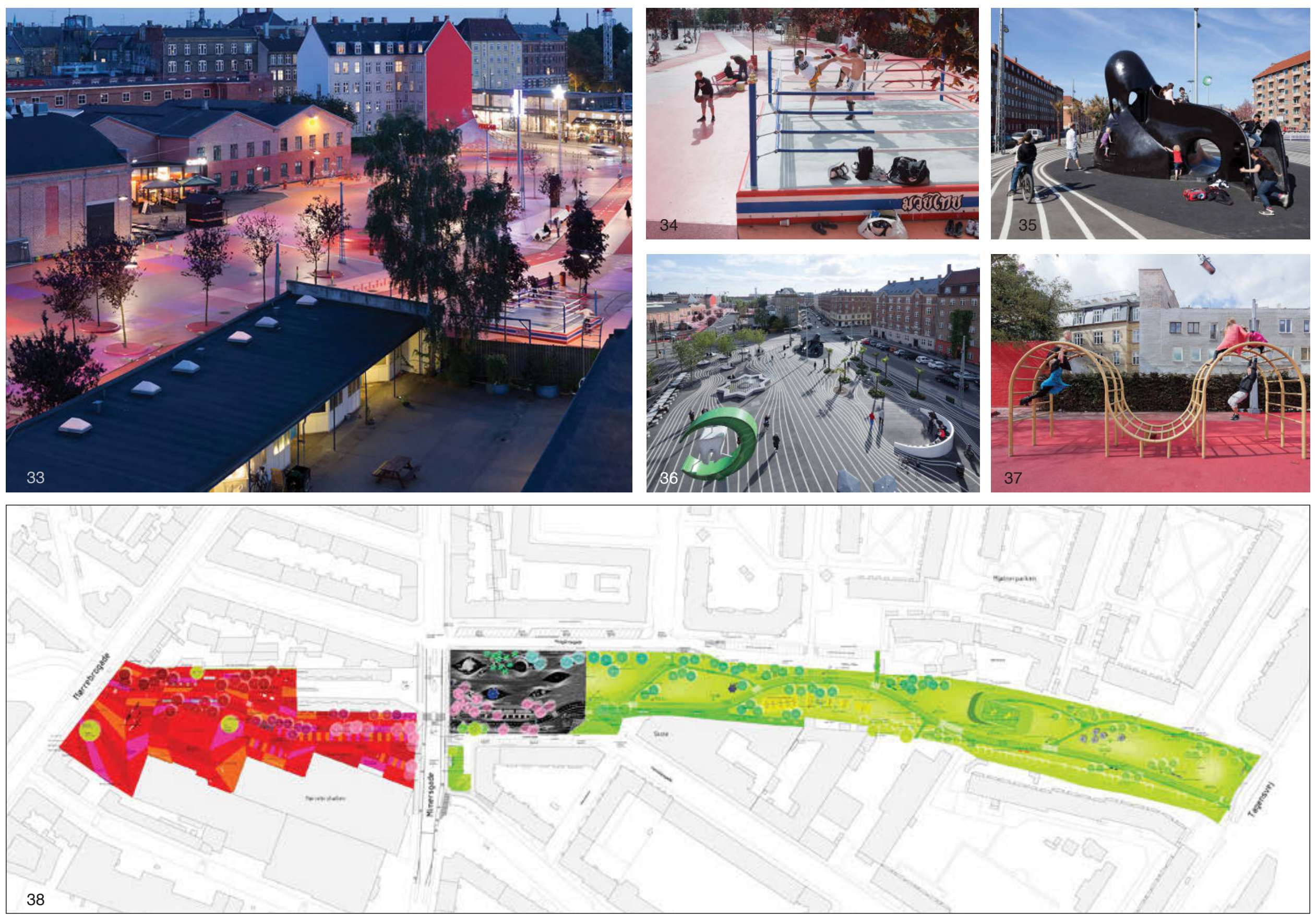

FIG. 33 - Night perspective of red segment

FIG. 34 - Boxing ring
FIG. 35 - Custom slide and play structure FIG. 36 - Seating in black segment
FIG. 37 - Jungle gym

FIG. 38 - Landscape of red, black, and green portions of the park 
more holistic community. St. James Town's narrative of ethnic diversity and low-income residents is mirrored in the Superkilen neighbourhood. The project seems to have increased the social capital in the community --- something St. James Town wishes to achieve. The urban park breathes new life into one of the most socially challenged neighbourhoods in Denmark. St. James Town shares the same storyline: an ethnically diverse population that seeks to connect its residents to each other, and the community to the city. This idea of linking the community back to the city via an urban park is explored in the design component of this thesis. 


\section{O DESIGN PROPOSAL}

This section of the thesis proposes a design to rehabilitate St. James Town by addressing the buildings' deficiencies and the community's needs. First, the proposal determines design drivers for the site, which are derived from the discussion of the neighbourhood's needs (see Section 4.3-4.6). The proposal then lays out an organizational scheme for a new urban park which includes additional housing, parking lots, communal areas, offices, and retail spaces. Lastly, this section addresses how the determined design drivers reinforce the neighbourhood scheme. 


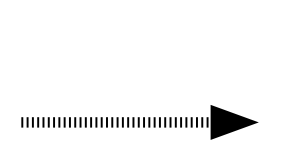

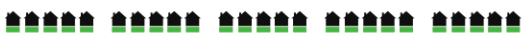

A

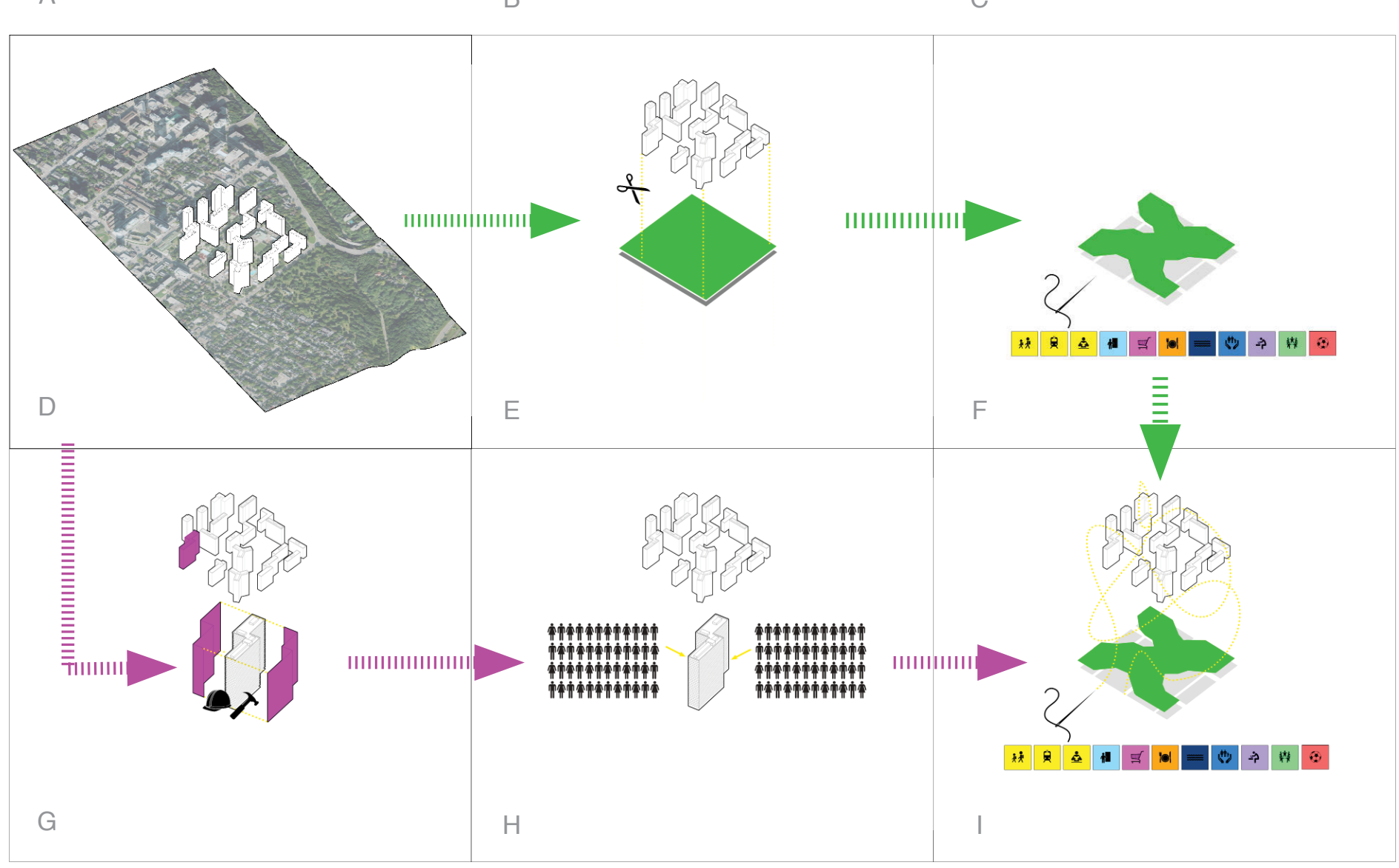

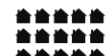

rates

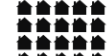

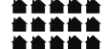

Prese
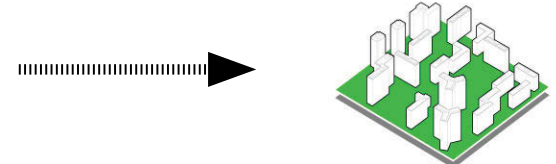

.
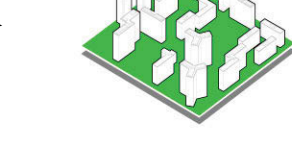

B

FIG. 39

Thesis Conceptual Design Narrative

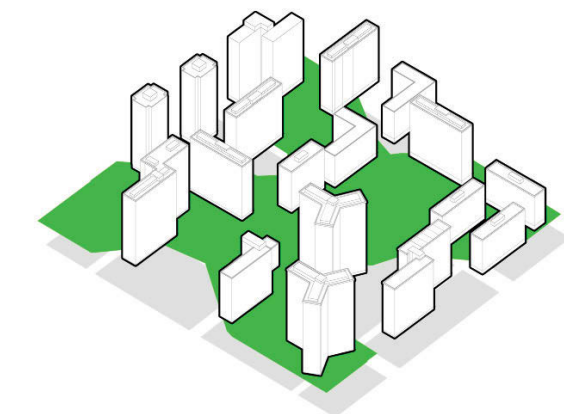

$J$

A. Original collection of victorian houses

B. The demolition and consolidation of homes into high-rise apartment towers

C. Existing form of St. James Town

D. Existing urban fabric of St. James Town

E. Conceptual divorce of towers from parks during design phase

F. Parks becomes social connectors between buildings providing access to amenities and recreation

G. The existing housing gets rehabilitated by upgrading building systems and installing a new facade

$H$. Buildings get designed for a greater number of inhabitants

The re-marriage of towers and parks to become a micro-city

J. The new towers-in-the-park 


\subsection{DESIGN DRIVGRS}

St. James Town is an ever-changing component of Toronto's urban landscape. The neighbourhood, which was originally designed to symbolize the rich diversity of the city, is now reduced to an eyesore of a landscape, comprised largely of patchy lawns, crumbling infrastructure, and a desolate ground plane. The landscape that was once envisioned to keep residents together now pulls them apart. A new landscape aims to replace the network of parking with programmed park space for the community. New housing strategies strive to alleviate the congestion of the units and improve upon the living conditions for the residents, while addressing their social needs. The design aims to bring residents together as a whole, and provide Toronto in general with a new urban landscape.

The following are five design drivers for the architectural intervention:

1. Maintaining the density of the neighbourhood, while alleviating the density of the buildings

2. Providing greater amounts of shared community spaces to service the residents

3. Mixed-income and family-friendly place making

4. Reconnecting with the street (and the city)

5. Interconnection of Residents, Buildings, and Parks to Foster Community 


\subsection{DESIGN STRATEGY}

A. Presently St. James Town is physically bounded by Bloor Street to the north, Sherbourne Street to the west, Wellesley Street to the south, and Parliament Street to the east. The St. James Cemetery, Toronto's oldest operating cemetery, stands across Parliament Street. North of the Bloor Street is a pedestrian bridge that crosses over a ravine. Southwest of the site is the commercial centre of Toronto.

B. St. James Town's buildings are placed within a network of concrete driveways, laneways, and surface parking lots that account for 18 percent of the total site area and total just under 35,000 square metres. This parking network was meant to serve the car oriented middle class when the community was initially built. With the site's actual population of low-to-moderate-income immigrants, however, the need for the car has declined and more emphasis is placed on access to public transit. This reliance on public rather than private transportation has left the majority of the surface parking lots underused. Moreover, the driveways that connect the streets to the parking lots also disconnect neighbouring buildings.

C. The St. James Town neighbourhood is presently comprised of high rise apartment towers, dilapidated houses, small retail shops, a couple of churches, an elementary school, a public library, and a subway station. 
D. The proposed design scheme for St. James Town includes the demolition of smaller residential and retail buildings that are mostly remnants from the initial 1870s neighbourhood. Although the houses have historical significance for having survived the block busting tactics of developers in 1960, they are presently abandoned and beyond repair. The City of Toronto temporarily experimented with using these houses as social housing, but the houses' poor states and significant age has made them too costly to maintain. The site's needs for a denser housing typology makes these buildings expendable. The demolition of these smaller buildings frees up larger park spaces as well as new building sites.

E. The remaining buildings serve as the organizational framework that the design will work within. The buildings that are remaining include 18 high rise towers ranging from 15 to 33 storeys, an elementary school, a community centre, a fire station, a Lutheran church, and an Anglican church.

F. There are social anchors and community services that are vital to the neighbourhood. The joint space of the public library and community centre, opened in 2004, is highly trafficked and demonstrates the desire for communal arenas. Rose Avenue Junior Public School has an approximate population of 650 students and is one of the largest elementary schools in the city. The school serves as the first place where many immigrant children from the community learn English, as 85 percent of the school's population speak English as a second 
language or are English Language Learners. The Lutheran and Anglican churches provide religious gathering spaces for residents. The fire station's close proximity to the neighbourhood ensures timely emergency services. Crucially, Sherbourne subway station acts as a transportation hub for the community with the majority of the inhabitants relying on public transit for their transportation needs.

G. The demolition of the dilapidated houses towards the north end of the site creates open space to be used for new housing and new park space.

H. A proposed new street consolidates all the laneways, driveways, and surface parking lots to provide more area for park space. The proposed street also helps to define the realm of the car and the realm of the pedestrian. The new street would now ensure that every building has their front door open onto the street with new park space in the back.

I. New park space acts as connecters for the residents and act as the link between the social anchors of the site.

J. Additional park space further ties the residents to a new retail and office strip along Sherbourne Street to the west and the cemetery across from Parliament Street to the east. 
K. More park connectors are used to draw in visitors from the private homes adjacent to St. James Town, as well as visitors from the subway station.

L. These new programmed park spaces transform a large proportion of the existing parking network into useable spaces for the community.

M. The new urban park for St. James Town consists of basketball courts, tennis courts, splash pools, ice rinks, benches, and a series of playground structure.

N. The parking lots and laneways that once separated residents of the community are converted into a collection of recreational activities for the community.

O. Smaller retail shops are concentrated into a new retail strip along Sherbourne Street. The street is the busiest in terms of foot traffic and car traffic. A new collection of smaller businesses on the ground floor along the street can feed off of the traffic from the city. New offices on the second and third floor also create places of work above the city streets

P. New elevator cores are installed to provide necessary relief for elevator congestion to minimize residents' wait times. 
Q. The massing of the new housing bars is formed from the structure of the existing towers. Some towers are connected to share facilities as well as to create a larger number of units. The new housing bars contain the existing tower floor plates but are also extended and bent to maximize street frontage.

R. Some of the new housing bars are porous along the ground plane to allow access into the park's recreation areas.

S. Each tower has a new greenhouse on the roof that acts as a community garden and can be used throughout the year. Each unit will be allotted with a plot size that they care for. These gardens fosters urban agriculture and provide residents with a stake in the community. The location of the greenhouses on the roof maximizes sun exposure. 

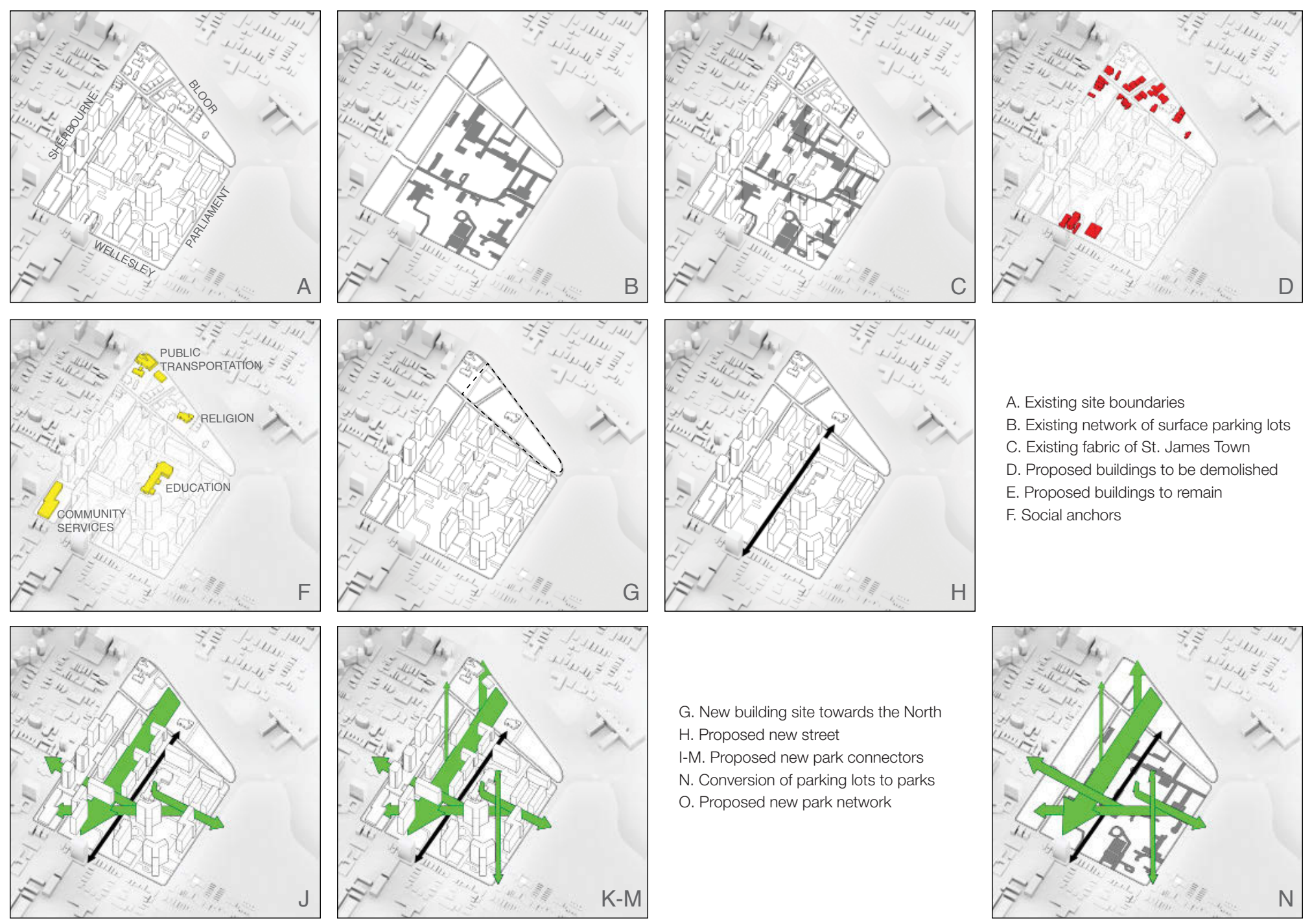

P. Park connections to housing

Q. Proposed new buildings from existing structures

R. New urban fabric

S. New rooftop greenhouses to promote urban agriculture

FIG. 40

Schematic Planning Narrative

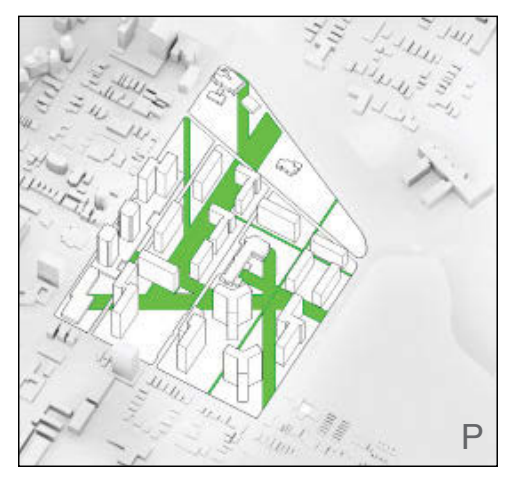

G. New building site towards the North H. Proposed new street

-M. Proposed new park connectors

N. Conversion of parking lots to parks

O. Proposed new park network

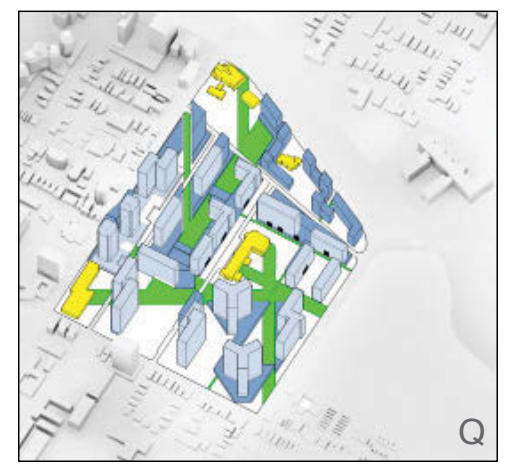

A. Existing site boundaries

B. Existing network of surface parking lots

C. Existing fabric of St. James Town

D. Proposed buildings to be demolished

E. Proposed buildings to remain

F. Social anchors

$\mathrm{H}$

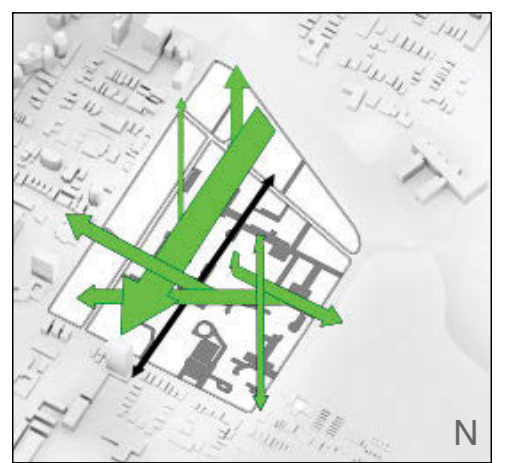

$\mathrm{N}$

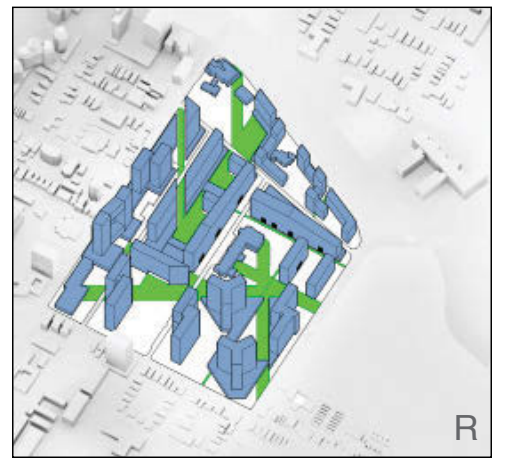

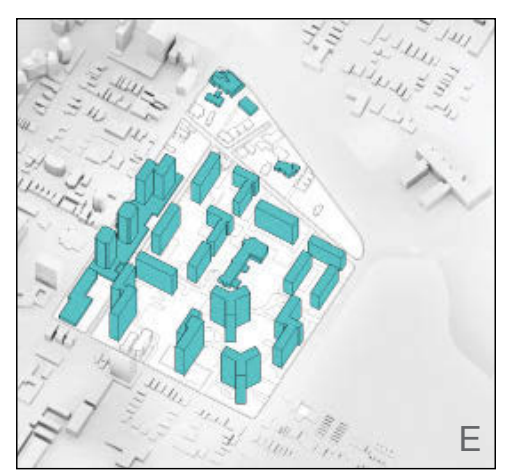
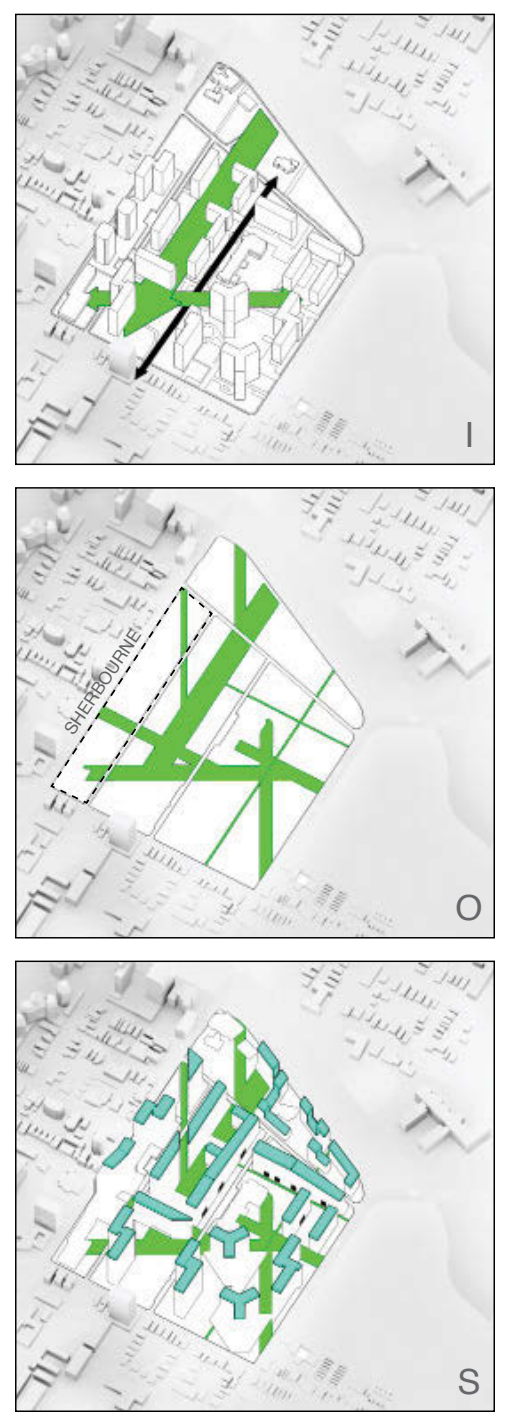
25,000 Residents Believed to live in

St. James Town

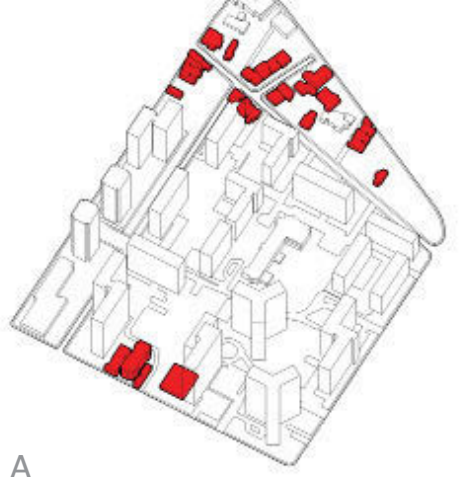

A

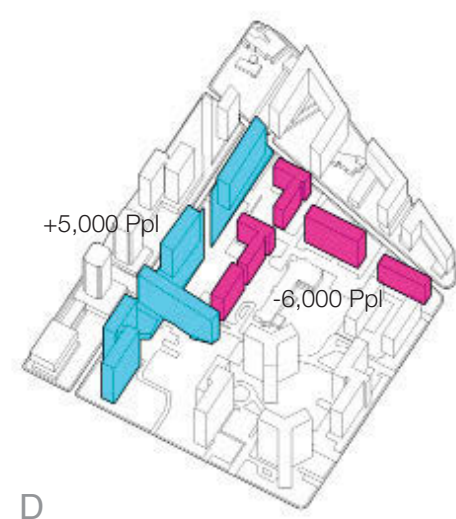

D

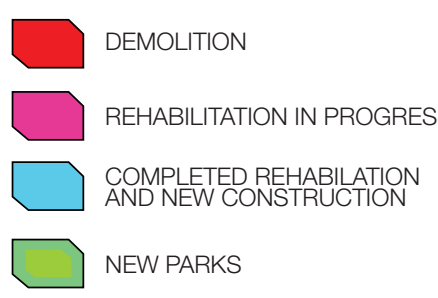

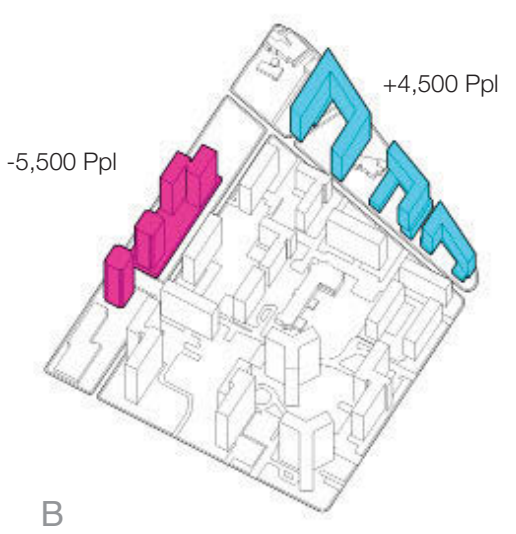
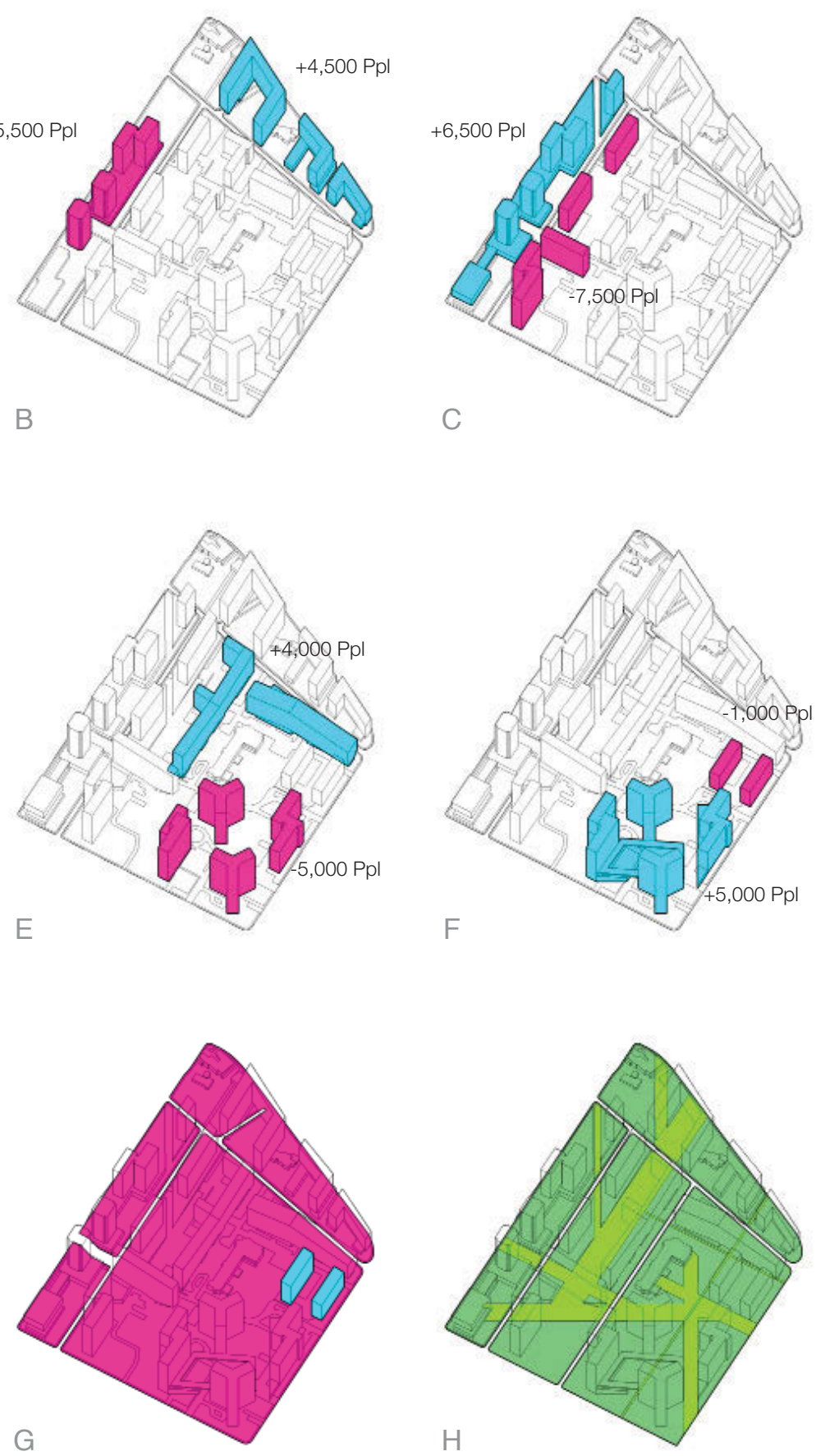

FIG. 41

Site Development Phasing Plan

A. Phase I - Demolition

B. Phase II

D. Phase IV

E. Phase V
F. Phase VI

G. Phase VII

H. Phase VIII

I. Completion

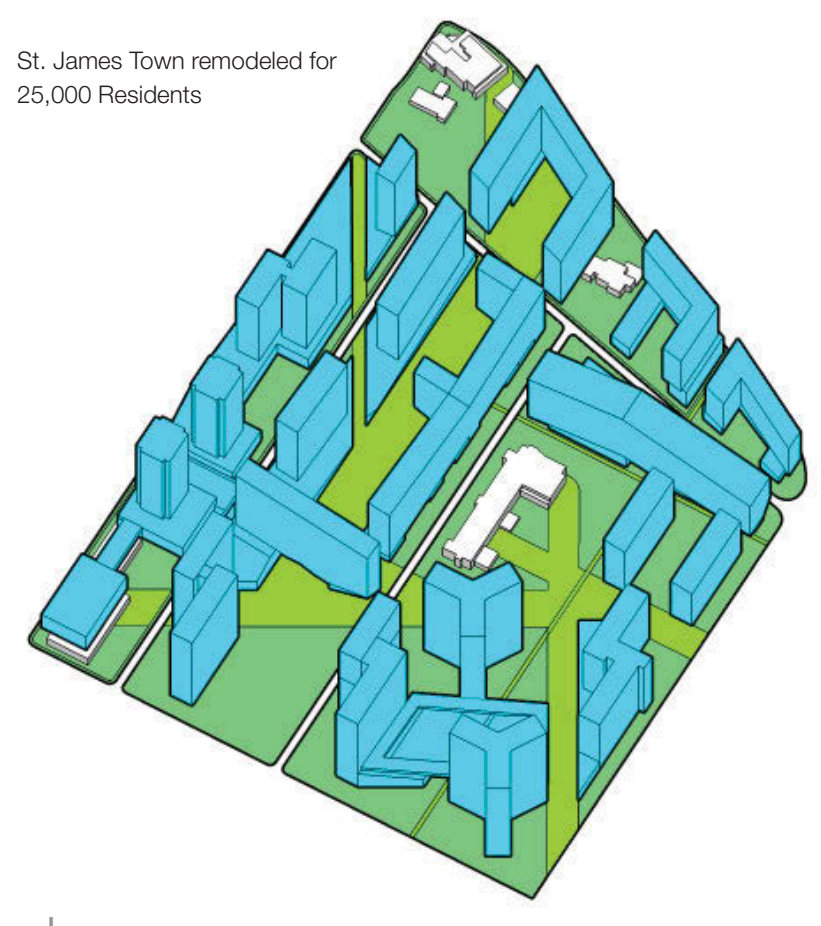




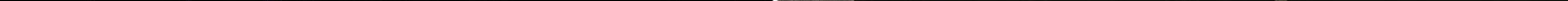




\subsection{DENSITY}

The design of this thesis firstly strives to create more units for the neighbourhood. This expansion aims to accommodate for the buildings' congestion by spreading units and residents out across the site. New units will be introduced by building on top of and in between existing buildings. The new buildings are formed from the existing floor plates and are porous on the park plane to allow pedestrian movement (See figure 17-18). The additional units will help to dilute the crowdedness within the existing towers. In addition to the increased number of units, the design also creates more amenities and recreational spaces to serve as community junction points. The challenge of this design proposal is to balance the creation of greater units with the preservation of potential park space.

The addition of units takes place in the form of expanding floor plates horizontally across the site; this allows some buildings to connect to others in order to share facilities and common areas. Other units are created by extending existing buildings upwards. The refurbishments to the existing stock are carried forward by stripping the buildings down to their structural concrete frames, which are said to be the only salvageable system in the building (discussed in Section 2.3). The balconies and masonry facades are stripped off the frame along with interior finishes and cabinetry. New building systems, elevators, and cladding are retrofitted onto the existing concrete framework.

The additional units that arise are also configured for a greater number of inhabitants. Some units create shelter for up to 10 dwellers, which represent the highest reported occupancy of individual units by landlords in the area. These units are retrofitted into the 


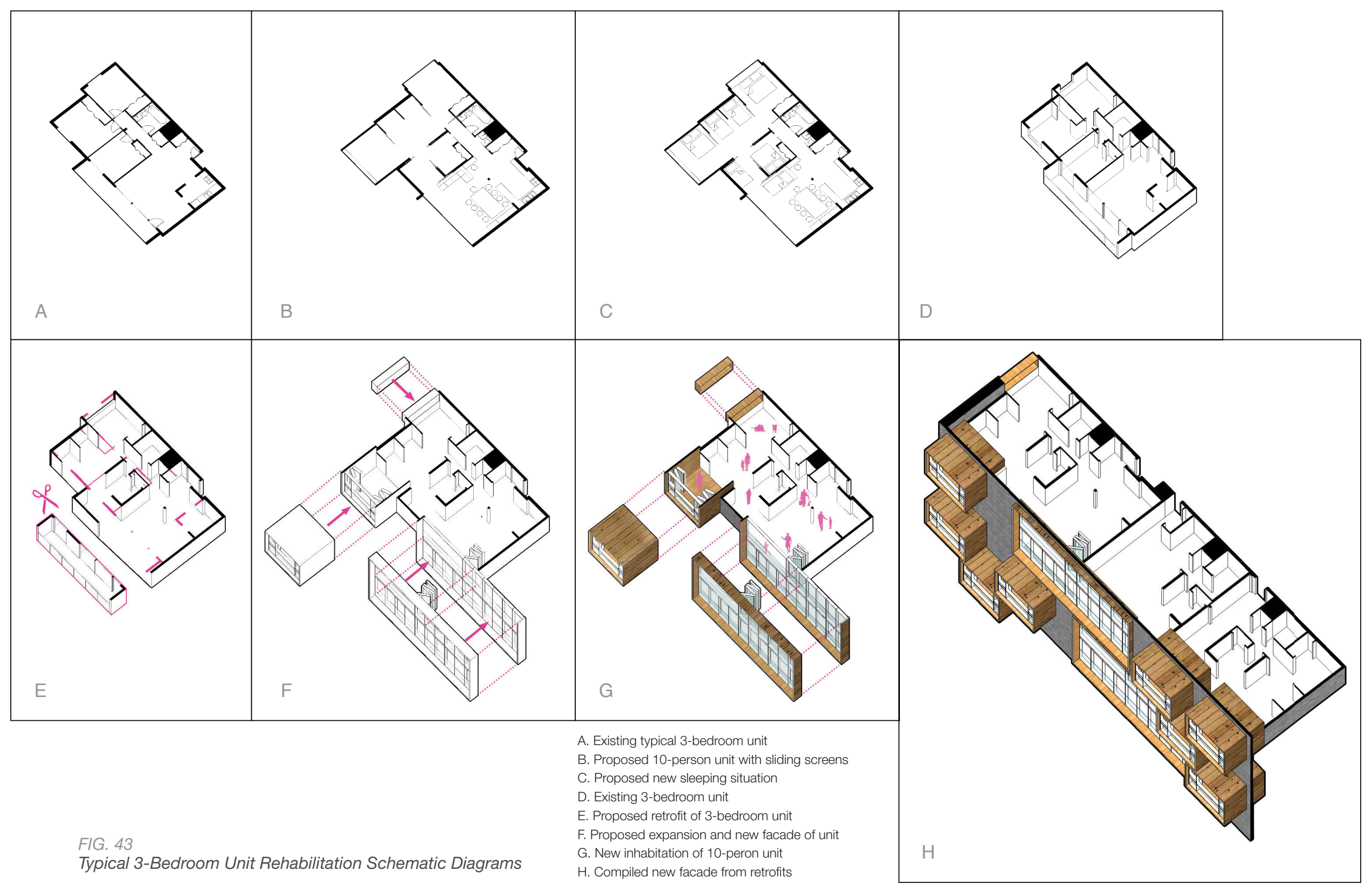


structural framework of the existing buildings. The units are 1,100 square feet, the average size of a 3 bedroom unit or the equivalent of 2 bachelor units of 550 square foot each. ${ }^{73}$ These units have built in walls and furniture that can slide and open up, allowing for both shared family space as well as private sleeping quarters. The current population is being forced to live in smaller quarters to share rent; thus, the units must be more efficient in their use of space in order to provide greater comfort and adaptability. The density of an individual building is balanced by amalgamating these units with less-dense

units. The less-dense units offer more square footage per person and cater to the moderate-to-high-income class. These efforts aim to promote denser urban living in the neighbourhood while at the same time relieve the feeling of crowdedness in the buildings.

\subsection{COMMUNITY SPACE}

The design recognizes the importance of community spaces by creating a more friendly and welcoming neighbourhood (see Section 2.5) and attempts to introduce them back into the fabric of St. James Town. The new community spaces are in both the urban park on the ground plane and within the buildings.

\footnotetext{
${ }^{73} \mathrm{G} \& \mathrm{~S}$ Group of Companies, Toronto Properties, http://kigono.com/gsgroup/index.cfm?controller=buildings\&action=show-
} buildings\&city=toronto, 20 November 2013. 


\subsubsection{COMMUNITY SPACE IN THE PARK}

The new design proposal for an urban park on the ground plane helps to tie together a fragmented community. A multifunctional space located near the elementary school at the centre of the site serves as the junction of three different park connectors. The space provides a forum where residents can hold community gatherings, such as outdoor assemblies, graduation ceremonies, and a farmer's market. The park also contains soccer pitches, basketball courts, and children-friendly play structures (discussed further

in Section 6.5). There is a reflecting pond that serves as a splash pad for children in the summer and as a skating rink the winter.

Furthermore, the park contains an artifact from the community. The 32-storey mural of a rising phoenix, which commemorates the 2010 fire that forced hundreds of residents from their 200 Wellesley Street apartment, is preserved during the rehabilitation and is reintroduced into the new urban park as the bed of a new reflecting pond that spans horizontally across the site. ${ }^{74}$ The mural will serve as the floor of the pond with water floating above. The shallow depth of the water allows the mural to be seen by the residents in the towers as a shimmering phoenix. The mural was created by volunteers from the community who came together during a time of crisis. This significant artifact is preserved to demonstrate the community's resiliency.

\footnotetext{
${ }^{74}$ Justin Skinner, 32-Storey Mural a Symbol for The St. James Town Community, Metro land Media, 08 August, 2013, http://www.insidetoronto.com/news-story/4024829-32-storey-mural-a-symbol-for-the-st-james-town-community/, 30 March, 2014.
} 


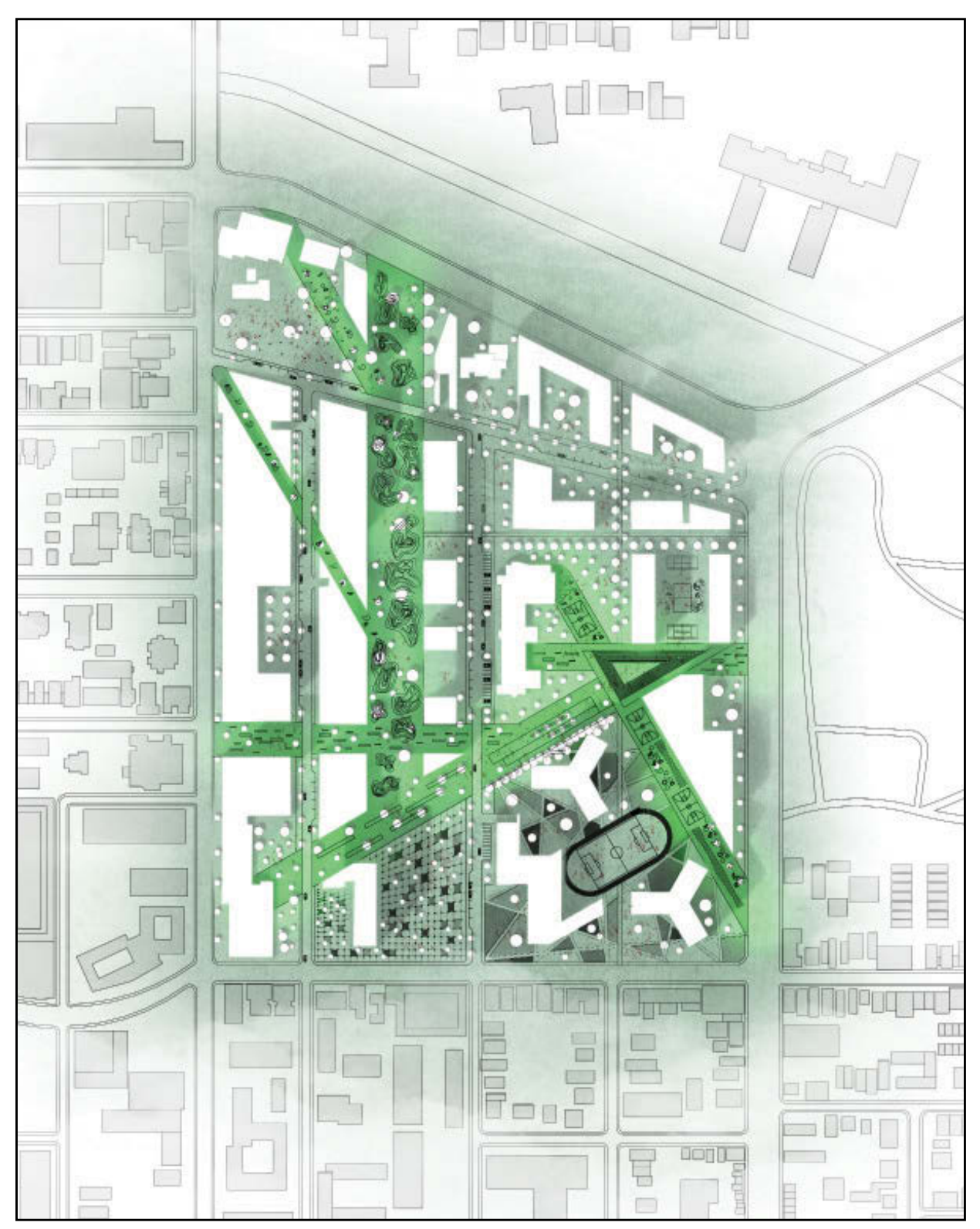

FIG. 44

New Landscape Plan

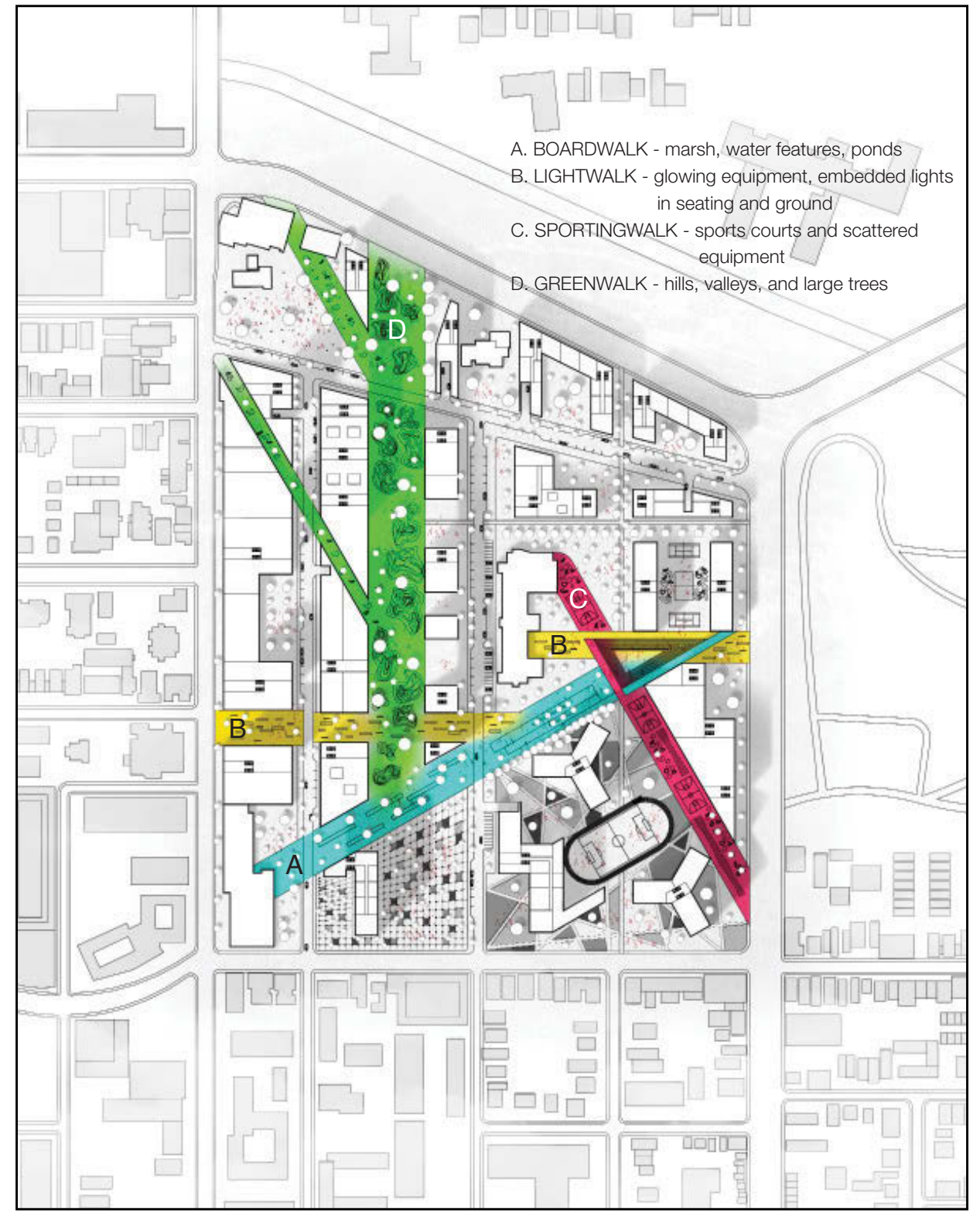

FIG. 45

New Landscape Connector Zones 

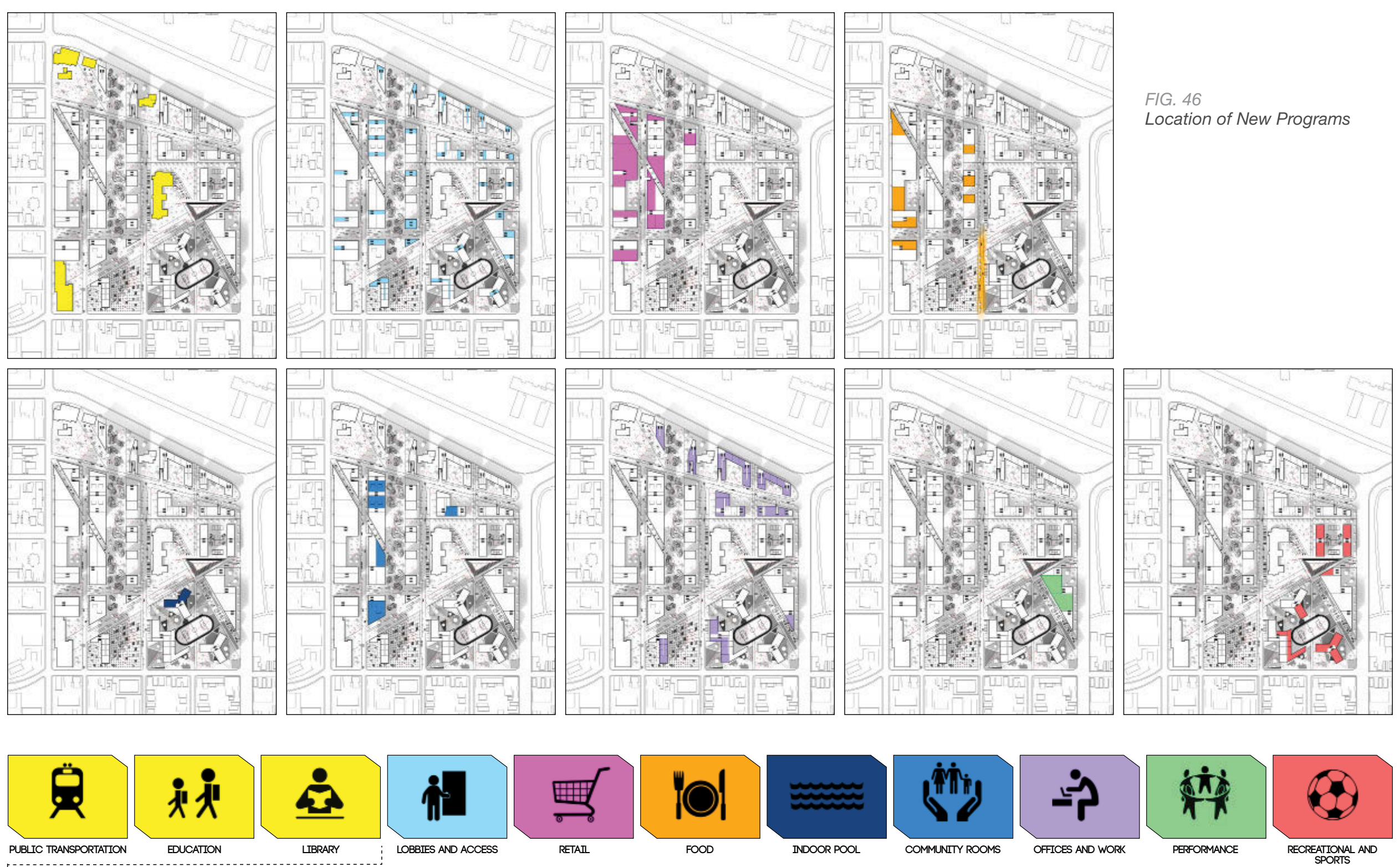

SOCIAL ANCHORS 


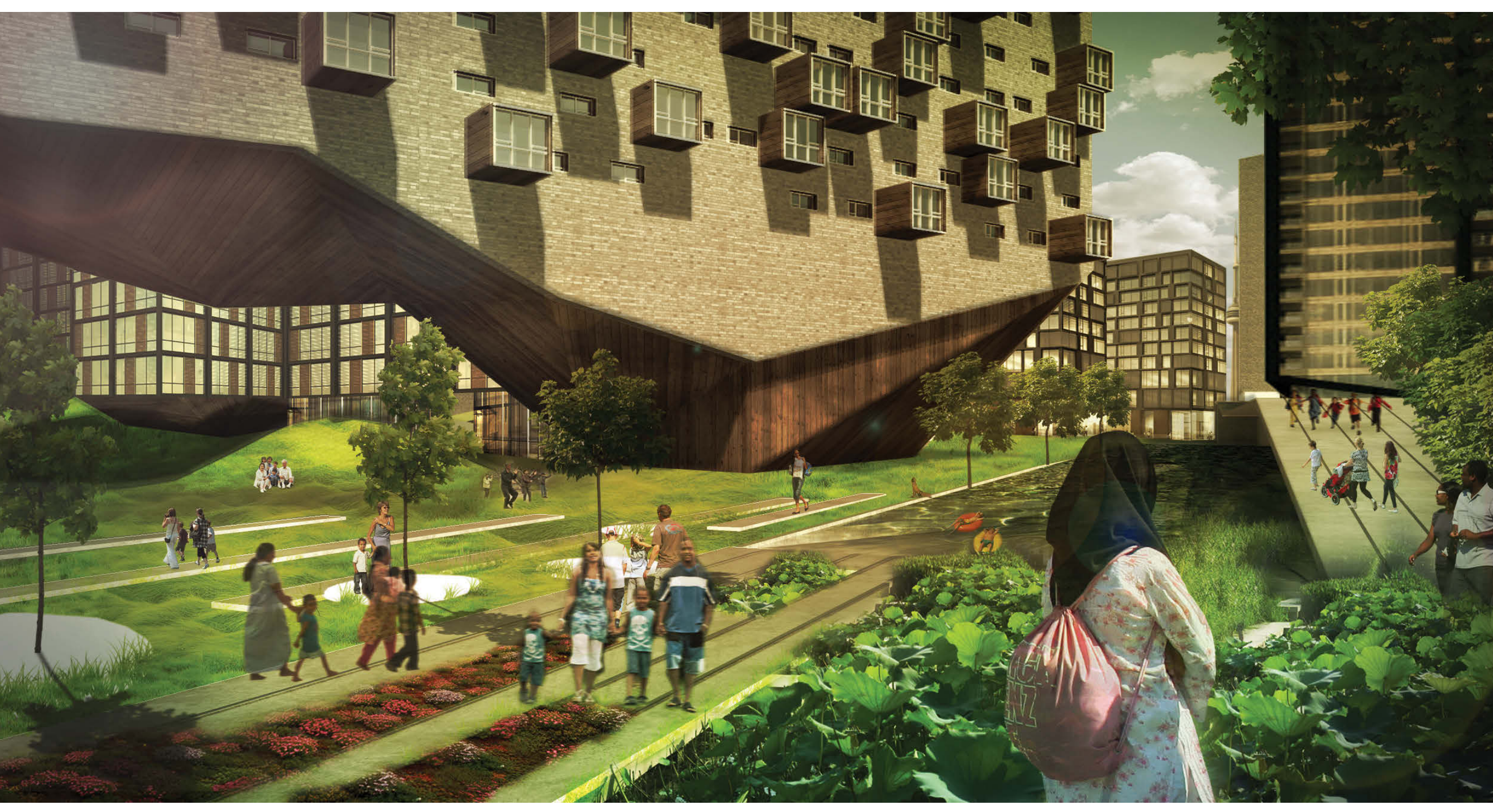

FIG. 47

St. James Town New Community Park Space During Summer 


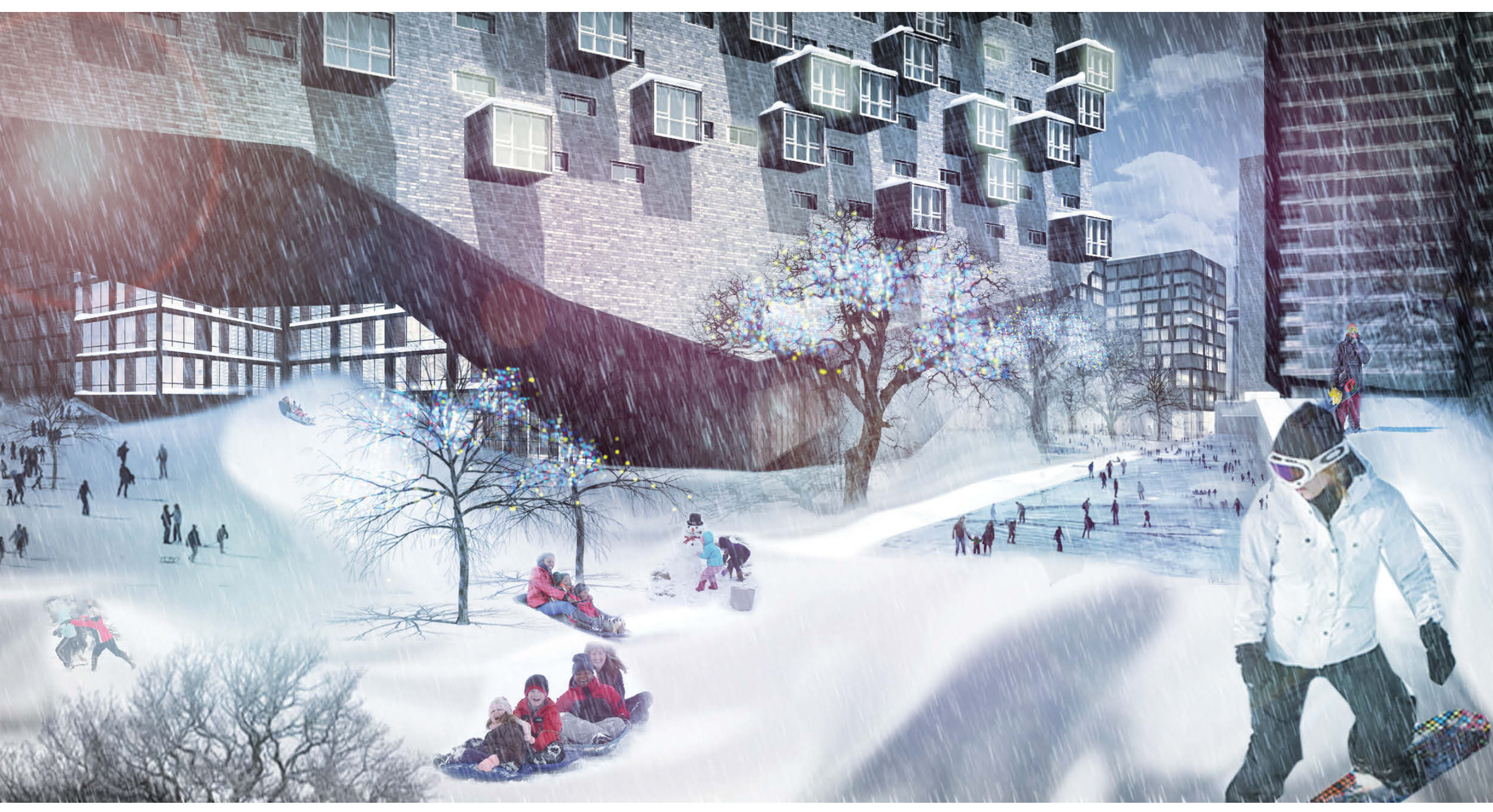

FIG. 48

St. James Town New Community Park Space During Winter 


\subsubsection{COMMUNITY SPACE IN THE TOWERS}

Along with community spaces in the proposed park, there are additional spaces such as games rooms, party rooms, theatres, basketball courts, and fitness facilities within the buildings. Greenhouses and community gardens are also added, allowing neighbours to come together to garden vegetables and plants. These greenhouses located on the rooftops of each building promote urban agriculture where residents are given a tangible stake in the community. The greenhouses are situated towards the southern facade and on the roofs of building to maximize exposure to sunlight. These greenhouses sustain garden growth year round and provide a retreat during the winter months.

\subsection{MIXED-INCOME AND FAMIIYFRIINDLY PLACE MAKING}

The demographics of St. James Town have changed drastically over the past forty years.

The buildings have come to accommodate low-income and ethnically diverse families. The design of the park space will contain children-friendly spaces by the use of objects like that of the Superkilen project (discussed in Section 5.2). These areas are focused around the elementary school in the middle of the community. Other pieces of play equipment are scattered throughout the area surrounding the school. These elements are located within the proposed park connectors. These play structures are intended to act as pavilions in the park. The concrete pavement is replaced with softer materials meant for children like rubber and Astroturf. Family units are located closer to the ground plane allowing parents to more easily observe their children. The proximity of the neighbourhood to Toronto's downtown core makes it a desirable destination for the 
middle class who wish to live closer to their places of work. The proposal's urban park and amenities serve as a draw for families and moderate-income households, in the hopes that they promotes a mixed-income neighbourhood. This balance can dilute the poverty concentration within buildings, reducing the possibility of neglect (discussed in Section 2.4). Integrating and scattering condominiums and row houses into the neighbourhood can also strengthen equity in the community and can promote an equilibrium amongst various classes.

\subsection{RECONNECTION WTTH THE STRET(AND THE CITY)}

As discussed, Jane Jacobs argued that the streets are the life force of the city. The park space at the base of the buildings acts as a threshold to the street and, as such, plays a significant role in reconnecting the buildings to the urban fabric. The neighbourhood seeks to unite itself with Sherbourne Street to the west, Howard Street to the north, Parliament Street to the east, and Wellesley Street to the south. These streets provide activity and traffic that are conducive to a new retail strip along the perimeter of the site. These new areas also act as the into the heart of the community and provide access to the park. A retail edge is established along Sherbourne Street by pulling the retail closer to the foot traffic of the sidewalk. Hard paving is used to dissolve the territory of the street into the area of the park, connecting the residents with the rest of the city. These pathways of park space spread out from the centre of the block to connect to the street and allow visitors to enter off of the street and into the neighbourhood. 


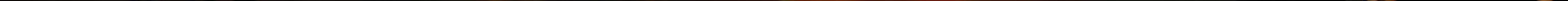




\subsection{INIERCONNECTION OF RESIDNETS, BUIDDNGS, AND PARKS TO FOSTER COMMUNITY}

Residents of the St. James Town neighbourhood have been delimited by fences, dumpsters, parking lots, and deteriorating infrastructure. Introducing a new urban park can holistically connect building residents with one another, as well as with other city residents. In order to link amenities and facilities such as indoor gymnasiums, theatres, and common rooms, this proposal adopts some of Linked Hybrid's techniques (Section 5.1). Covered pedestrian bridges connect adjacent buildings' communal spaces. This bridges allow an interconnection of different buildings, creating a larger neighbourhood network within St. James Town. These connectors provide shelter during the winter months and allow residents to enjoy the facilities year round. Promoting porous spaces through buildings and passages for the public aims to promote community interaction. This design maintains sight lines from the buildings to the park below as well as to the skyline. The interconnection between recreational programs and common spaces aims to nurture a greater cohesion in the community while allowing residents to share facilities.

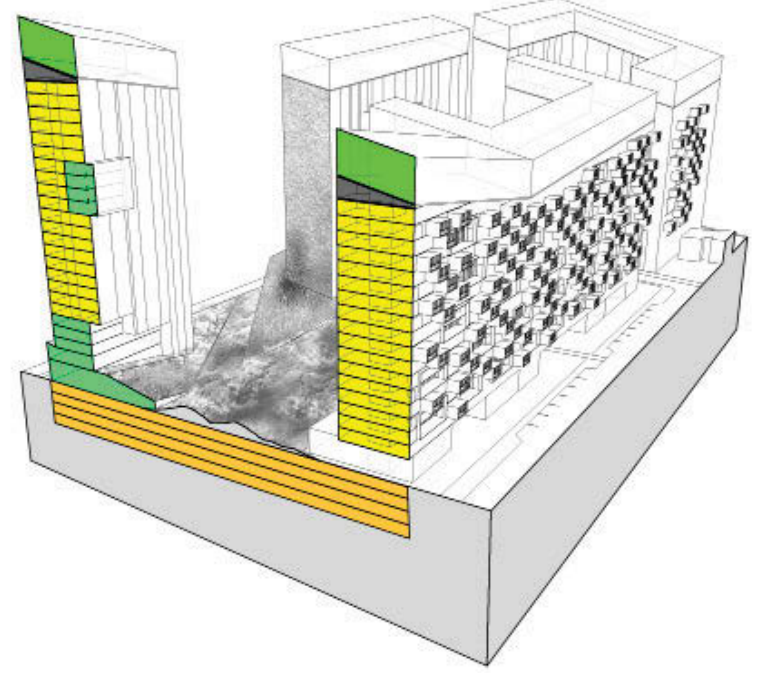




\subsection{SUMMARY \&

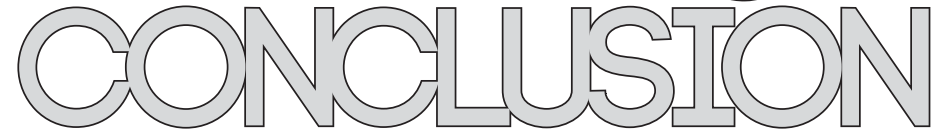

The towers-in-the-park were a modernist model that opened up the ground plane and vertically extended housing to provide park space. Toronto city planners, officials, and developers favoured this form during the 1960s and 1970s. Through it, they developed more than 1,000 apartment buildings and housed over 1,000,000 people. These pieces of modernity, that were once celebrated, grew to assume the blame for their inhabitants' social isolation and economic poverty. This thesis argues that the architecture is not solely to blame. A combination of social forces led to the downfall of these buildings. The loss of community spaces, the changing demographics, and the neglect of the building owners also share blame. Newcomers and low-income families, in search of affordable housing, flocked to these vertical villages. The high-rise towers are fixtures in Toronto's urban fabric and are thus valuable resources to both its residents and the city. This thesis hopes to convey that these towers should be celebrated for their diversity, their accommodations for the low-income class, as well as their service to urban growth in Toronto.

The stigmatized high-rise apartment towers are often home to newcomers and lowincome families. The towers are condemned for their associations with crime and drugs, generally causing people to avoid them. Statistics debunk this stereotype by showing that these towers have the same crime rate as the rest of the city. Statistics also show that these apartments include educated and socially adept immigrants. Tenants reported feeling safe, and they thought these towers were good places in which to live. The residents spoke of camaraderie within the buildings: they can seek support from residents 
who shared nationalities or languages. General members of the public, who do not see the rich community life in these buildings, inaccurately refer to them as blights to the city. These towers have their flaws, but this design highlights their positive potentials.

The proposal remedies the urban density, social isolation, and economical and physical disconnection of St. James Town. The use of park space at the base of the buildings shows that denser living does not have to result in crowdedness. Better use of the park space increases the recreational spaces of the neighbourhood. The community benefits from having spaces where residents can interact with one another and escape the confines of their units. This ensures that community life is not sequestered within the building but can also be fostered around them, even bridging to neighbouring buildings. The demographics of St. James Town drastically changed from its initial conception. Subsequently, the needs of the neighbourhood has also changed. More emphasis is placed on creating a mixed-income and family-friendly atmosphere. The reconfiguration of units and addition of unit types appropriate for families helps to facilitate a diverse demographic. In addition to new housing units and recreational park spaces, there were also new retail and office spaces along Sherbourne Street. This new retail strips helps to connect the community with the rest of Toronto through the reconnection of the street. A new proposed street running north-south on the site also creates new street entrances for the housing towers. Each tower faces a street in the front and backs onto park space behind. This defines the front yard and backyard of the building.

The proposed design of the St. James Town community helps to illuminate that rehabilitation is possible. The design can provide hope for the rehabilitation of the other 
hundreds of high-rise clusters scattered throughout the city. The initial St. James Town development in the 1960s was as a model for Toronto's high-rise future. This design project can be seen as the evolution of that model by creating a city within a city. The proposal remedies issues of population density, fostering social capital, uniting income classes, generating business, facilitating education, and providing community services, which are the essential ingredients to a healthy city. The 1960s scheme led to thousands of towers and hundreds of high-rise communities in the GTA. This new scheme can serve as a way to help those vertical communities evolve and become cities in themselves. 


\section{BIBLIO GRAPHAM}

Alexiou, Alice Sparberg. Jane Jacobs: Urban Visionary (Toronto: HarperCollins Publishers Ltd, 2006).

Allen, Max. Ideas That Matter: The Worlds of Jane Jacobs (Washington: Island Press, 2011).

Arendt, Hannah. The Human Condition, 2nd ed. (Chicago: The University of Chicago Press, 1958).

Basrur, Sheela. Physical Activity and Public Health: A Call to Action, Medical Officer of Health (City of Toronto Staff Report, 2013).

Bjarke Ingels Group, Superkilen, http://www.big.dk/\#projects-suk, 20 October 2013.

Brantz, Dorothee and Sonja Dumplemann. Greening the City: Urban Landscapes in the Twentieth Century (Virginia: University of Virginia Press, 2011).

G\&S Group of Companies, Toronto Properties,

http://kigono.com/gsgroup/index.cfm?controller=buildings\&action=showbuildings\&city=toronto, 20 November 2013

Cabbagetown Preservation Association Newsletter. Breezes of Change Lift St. James Town (Autumn 2012).

Canada: Immigration Act, 1976-77, c. 52, s. 1, National Legislative Bodies, 1976 , http://www.refworld.org/docid/3ae6b5c60.html, 3 February 2014.

Caulfield, Jon. City Form and Everyday Life: Toronto's Gentrification and Critical Social Practice (Toronto: University of Toronto Press, 1994).

Chermayeff, Serge and Alexander Tzonis, Shape of Community: Realization of Human Potential (Hardmondsworth: Penguin Books Ltd, 1971).

City of Toronto, Toronto's Racial Diversity, 2013, http://www.toronto.ca/toronto_facts/diversity.htm, 3 February 2014. 
Community Foundations of Canada, 2009 Vital Signs Report, and Spacing Magazine (Winter 2009).

Conrads, Ulrich. Programs and Manifestos on 20th-Century Architecture (London: MIT Press, 1971)

Cook, Edward A. and Jesus J. Lara. Remaking Metropolis: Global Challenges of the Urban Landscape (London: Routlege, 2013).

Dutton, John. Plan of the Month: Smithson's Golden Lane Project (1952) 26 May 2013, http://www.grids-blog.com/wordpress/plan-of-the-month-smithsons-golden-laneproject-1952/, 25 March, 2014.

E.R.A. Architects and the University of Toronto, Mayor's Tower Renewal Opportunities Book (Toronto: City of Toronto, 2008).

Fainstein, Susan S. and Scott Campbell. Readings in Planning Theory, 3rd Edition (United Kingdom: John Wiley and Sons Ltd, 2012).

Farrow, Jane. Walkability in Toronto's Apartment Neighbourhoods: Preliminary Report on St. James Town Walkability Workshop (Toronto: 2009).

Ferre, Albert. Total Housing: Alternatives to Urban Sprawl (Barcelona: Actor, 2010).

Frampton, Kenneth. Modern Architecture: A Critical History,4th ed. (London: Thames and Hudson Ltd, 2007).

Gaventa, Sarah. New Public Spaces (London: Mitchell Beazley, 2006).

Goldsmith, Stephen A. and Lynne Elizabeth. What We See: Advancing the Observations of Jane Jacobs (Oakland: New Village Press, 2010).

Hardwicke, Chris. City of Homes, Spacing, (Spring 2010).

Harvey, David. Fertile Ground for New Thinking: Improving Toronto's Parks (Toronto: Metcalf Foundation, 2010).

Hirt, Sonia and Diane Zahm. The Urban Wisdom of Jane Jacobs (London: Routledge, 2012). 
Krause, Linda. Sustaining Cities: Urban Policies, Practices, and Perceptions (New Jersey: Rutgers University Press, 2013).

Kennedy, Brendan. Over a million living in highrises have been largely ignored, The Toronto Star, 05 December 2010,

http://www.thestar.com/news/gta/2010/12/05/over_a_million_living_in_highrises_have_ been_largely_ignored.html, 15 January, 2014.

Le Corbusier. Towards a New Architecture. Translated by Frederick Etchells (New York: Dover Publications Inc, 1986).

Loew, Sebastian. Urban Design Practice: An International Review (London: RIBA Publishing, 2012).

MacDonnel, Susan. Poverty By Postal Code 2: Vertical Poverty (Toronto: United Way, 2013).

McClelland, Michael and Graeme Stewart. Concrete Toronto: A Guidebook to Concrete Architecture From the Fifties to the Seventies (Toronto: Coach House Books, 2007).

McGrath, Brian. Urban Design Ecologies (United Kingdom: John Wiley and Sons Ltd, 2013).

Micallef, Shawn. Stroll: Psychogeographic Walking Tours of Toronto (Toronto: Library and Archives Canada Cataloguing in Publication, 2010).

Miron, John R. Housing in Postwar Canada: Demographic Change, Household Formation, and Housing Demand (Montreal: McGill-Queen's University Press, 1988).

Moor, Malcolm and Jon Rowland. Urbanism Design Futures (New York: Routledge, 2006).

Moore, Oliver. The Canadian Commute: By Car Alone, The Globe and Mail, 26 June 2013, http://www.theglobeandmail.com/news/national/the-canadian-commute-by-caralone/article12849501/, 15 December 2013.

Moskow, Keith and Robert Linn. Small Scale: Creative Solutions for Better City Living (New York: Princeton Architectural Press, 2009). 
Murray, Glen and Pam McConnel, Community Action Plan: Draft Report - St. James Town (Toronto: 2011).

Neumann, Brigette, Richard Mezoff and Anthony H. Richmond. Immigrant Integration and Urban Renewal in Toronto (The Hague: Martinus Nijhoff, 1973).

Ontario Population Projections Update, Ontario Ministry of Finance, Spring 2013,

http://www.fin.gov.on.ca/en/economy/demographics/projections/, 21 February 2014.

Perkins, Kevin and Tom Zizys, St. James Town Neighbourhood Toronto: Overview and Prospects for Community-Based Poverty Alleviation Initiatives (Toronto: World Vision Canada, 2005).

Population estimates for Toronto, Canada, 1950-2015, http://books.mongabay.com/population_estimates/full/Toronto-Canada.html, 25 February 2014.

Ruan, Xing. New China Architecture (Singapore: Periplus Editions Ltd, 2006)

Schwartz, Martha. Recycling Spaces, Curating Urban Envolution: The Landscape Design of Martha Schwartz Partners. Edited by Emily Waugh (London: Thames and Hudson Ltd, 2011)

Sewell, John. The Shape of the City: Toronto Struggles With Modern Planning (Toronto: University of Toronto Press, 1993).

Sewell, John. Houses and Homes: Housing for Canadians (Toronto: James Lorimer and Company Publishers, 1994).

Skinner, Justin. 32-Storey Mural a Symbol for The St. James Town Community, Metroland Media, 08 August, 2013, http://www.insidetoronto.com/news-story/4024829-32storey-mural-a-symbol-for-the-st-james-town-community/, 30 March, 2014.

Sukerkilen/Topotek 1 + BIG + Superflex, Archdaily, 25 October 2012, http://www.archdaily.com/286223/superkilen-topotek-1-big-architects-superflex/,30 March 2014 
Steven Holl Architects, Linked Hyrbid, http://www.stevenholl.com/project-detail.php?id=58, 16 October, 2013.

Statistics Canada, Low Income Cut-offs, 2 May 2013,

http://www.statcan.gc.ca/pub/75f0002m/2012002/lico-sfr-eng.htm, 15 January, 2014.

Scallan, Niamh. Density Toronto: As GTA population rises, so do expectations for denser living, The Toronto Star, 19 October 2012,

http://www.thestar.com/news/gta/2012/10/19/density_toronto_as_gta_population_rise S_so_do_expectations_for_denser_living.html, 12 November, 2013.

The Canadian Press, Toronto has the lowest crime rate of Canada's census metropolitan areas, City News Toronto, 25 July 2013, http://www.citynews.ca/2013/07/25/torontohas-lowest-crime-rate-of-canadas-census-metropolitan-areas/, 21 February 2014.

Vroom, M.J. and J.H.A. Meeus. Learning From Rotterdam: Investigating the Process of Urban Park Design (New York: Mansell Publishing, 1990). 